\title{
Coastal waters freshening and extreme seasonality affect organic matter sources, quality, and transfers in a High Arctic fjord (Young Sound, Greenland)
}

\author{
Bridier Guillaume ${ }^{1,{ }^{*}}$, Meziane Tarik ${ }^{2}$, Grall Jacques ${ }^{1,3}$, Chauvaud Laurent ${ }^{7}$, Sejr Mikael Kristian 4, , \\ Menneteau Sylvain ${ }^{1,2}$, Olivier Frederic ${ }^{2,6}$
}

1 UBO, Lab Sci Environm Marin LEMAR, UMR 6539, IRD, Ifremer,CNRS, Rue Dumont DUrville, F29280 Plouzane, France.

2 UCN, Biol Organismes \& Ecosyst Aquat BOREA, UMR 7208, MNHN,IRD,SU,CNRS,UA, 61 Rue

Buffon CP53, F-75005 Paris, France.

3 Inst Univ Europeen Mer, Observ Marin, UMS 3113, Rue Dumont DUrville, F-29280 Plouzane, France.

${ }^{4}$ Aarhus Univ, Arctic Res Ctr, Ny Munkegade Bldg 1540, DK-8000 Aarhus C, Denmark.

${ }^{5}$ Aarhus Univ, Dept BioSci, Vejlsovej 25, DK-8600 Silkeborg, Denmark.

${ }^{6}$ Museum Natl Hist Nat, Stn Marine Concarneau, PI Croix, F-29900 Concarneau, France.

* Corresponding author : Guillaume Bridier, email address : guillaume.bridier@live.ie

\begin{abstract}
:
Arctic benthic ecosystems are expected to experience strong modifications in the dynamics of primary producers and/or benthic-pelagic coupling under climate change. However, lack of knowledge about the influence of physical constraints (e.g. ice-melting associated gradients) on organic matter sources, quality, and transfers in systems such as fjords can impede predictions of the evolution of benthic-pelagic coupling in response to global warming. Here, sources and quality of particulate organic matter (POM) and sedimentary organic matter (SOM) were characterized along an inner-outer gradient in a High Artic fjord (Young Sound, NE Greenland) exposed to extreme seasonal and physical constraints (ice-melting associated gradients). The influence of the seasonal variability of food sources on 2 dominant filterfeeding bivalves (Astarte moerchi and Mya truncata) was also investigated. Results revealed the critical impact of long sea ice/snow cover conditions prevailing in Young Sound corresponding to a period of extremely poor and degraded POM and SOM. Freshwater inputs had a very local impact during summer, with relatively more degraded POM at the surface compared to bottom waters that were less nutritionally depleted but more heterogeneous among the sampled stations. Terrestrial inputs contributed to the SOM composition but showed a large variability along the fjord. Finally, diet analyses underlined the contrasted nutritional conditions, showing much higher lipid reserves in A. moerchi than in M. truncata during winter. Under a scenario with increased freshwater input, such results suggest a decline in organic matter quality and production in Young Sound, with subsequent impacts on benthic food webs.
\end{abstract}

Keywords : Arctic ecosystems, Benthic-pelagic coupling, Organic matter, Climate change, Fatty acids, Stable isotopes, Young Sound 


\section{INTRODUCTION}

The Arctic has been subjected to atmospheric warming in recent decades at a rate that exceeds the global average by a factor of 2-3 (AMAP 2017). This warming induces major modifications in the Arctic marine environment, e.g., a decrease in sea-ice cover (extent and thickness) and an increase in freshwater discharge (AMAP 2017, Kwok \& Rothrock 2009, McPhee et al. 2009, Ohashi et al. 2016). The Greenland Ice Sheet annual net loss is currently estimated at $186 \mathrm{Gt}^{-y^{-}}$ ${ }^{1}$, which is double the melting rate observed for 1983-2003 (Bamber et al. 2012, Kjeldsen et al. 2015). Such changes are expected to impact marine systems through shifts in the spatial distribution of species (Falk-Petersen et al. 2007) and altered food web dynamics via modified quantity, quality, and seasonal timing of primary productivity (Iken et al. 2010, Leu et al. 2011, Ardyna et al. 2014, Arrigo \& van Dijken 2015). Moreover, changes in the phenology of primary producers may create mismatches between peak algal blooms and faunal reproductive phases, with major effects on the benthic-pelagic coupling (Søreide et al. 2010, Moran et al. 2012).

Several authors have modeled the evolution of food webs and marine wildlife within a changing Arctic (e.g., Wassmann 2011, Kędra et al. 2015). However, recent studies indicate a regionally variable Arctic ecosystem response to global warming depending on specific habitat characteristics (e.g., water depth, exposure to terrestrial runoff; Carmack et al. 2015, De Cesare et al. 2017, Gaillard et al. 2017). For instance, although the generally accepted paradigm states an increase in primary production in the Arctic Ocean, the opposite trend could occur in coastal areas (which represent $35 \%$ of the world's coastline) such as fjord systems, due to the increase in freshwater inputs and subsequent turbidity (Carmack et al. 2015, Middelbo et al. 2018). Terrestrial runoff from melting snow and ice increases water column turbidity and diminishes light availability, in turn decreasing primary productivity (Murray et al. 2015, Arimitsu et al. 2016). Freshwater inputs also reduce primary productivity in some fjords due to increased stratification, causing nutrient depletion in surface waters (Piquet et al. 2014, Meire et al. 2016, 
Middelbo et al. 2018). On the other hand, freshwater inputs from glacier melting may provide labile organic carbon, which may be a source of bioavailable carbon in low-productivity ecosystems (Lawson et al. 2014). The impact of increased freshwater loads on the quality of organic matter and transfers in Arctic fjords remains poorly understood.

We conducted a sampling program during August 2016 and May 2017 in a High Arctic fjord (Young Sound, NE Greenland) to study how seasonal and physical constraints drive the sources and qualitatively change the organic matter available for dominant benthic primary consumers: the abundant filter-feeding bivalves Astarte moerchi and Mya truncata (Sejr et al. 2000, Born et al. 2003). Potential bivalve food sources and body tissues were analyzed for fatty acid (FA) and stable isotope (SI) composition. FA analysis can be used to trace the origin of organic matter within an environment, since primary producers often show contrasting FA profiles according to their taxonomic group (e.g., diatoms, dinoflagellates, macroalgae; Meziane \& Tsuchiya 2000, Dalsgaard et al. 2003, Kelly \& Scheibling 2012). Moreover, biosynthesis of specific FAs, such as polyunsaturated FAs (PUFAs), is usually limited in marine bivalves. This enables the use of FA trophic markers to study diet (Kelly \& Scheibling 2012, Thyrring et al. 2017). SI analysis may also help to characterize the trophic diet of organisms (Fry 2006, Gaillard et al. 2017) and to investigate environmental processes occurring within an ecosystem, such as inputs of terrestrial carbon (Calleja et al. 2017), organic matter degradation (McTigue et al. 2015), or the dynamics of blooms (Tamelander et al. 2009).

The main goals of this study were to (1) understand how seasonal and physical constraints in Young Sound may influence the sources and quality of pelagic organic matter (POM) and sedimentary organic matter (SOM), (2) assess the seasonal patterns (ice/snow cover in May vs. open sea in August) of organic matter transfers within this fjord, and (3) investigate the response of two dominating bivalve species (A. moerchi and M. truncata) to such seasonality in food availability. 


\section{Study site and sampling}

109 The study was conducted in Young Sound ( $74^{\circ} \mathrm{N} 20^{\circ} \mathrm{W}$, Fig. 1), a High Arctic Greenland fjord 110 characterized by a long sea-ice duration of 9-10 months (Glud et al. 2007). The fjord is 111 approximately $90 \mathrm{~km}$ long and 2-7 km wide. The maximum depth is $330 \mathrm{~m}$, but exchange with 112 coastal waters is limited by a shallow sill with a depth of $45 \mathrm{~m}$ at the mouth of the fjord 113 (Bendtsen et al. 2007). During land-glacier and snow melting, the surface waters become more 114 turbid and brackish due to freshwater inputs, especially in the inner part of the fjord (Ribeiro et 115 al. 2017). Generally, such freshwater inputs generate a bilayer estuarine water circulation with

116 low-salinity surface flows from the inner to the outer fjord and inflows occurring close to the seabed (Bendtsen et al., 2014). Young Sound has the typical surface current circulation in fjords affected by the Coriolis effect, with the southern part (Clavering Island side) more exposed to freshwater outflow than the northern part (Wolloston Forland side; Bendtsen et al. 2007).

Sampling was conducted in August 2016 (open water, early productive period; De Cesare et al. 2017) and May 2017 (ice cover, expected "unproductive" period). We sampled three stations in 2016 (Fig. 1), i.e., Pass Hytten (depth $=18 \mathrm{~m}, 74.41^{\circ} \mathrm{N} 20.33^{\circ} \mathrm{W}$ ), Basalt Island (depth = $21.5 \mathrm{~m}, 74.33^{\circ} \mathrm{N} 20.36^{\circ} \mathrm{W}$ ), and Kap Breusing (depth $\left.=20 \mathrm{~m}, 74.21^{\circ} \mathrm{N} 20.11^{\circ} \mathrm{W}\right)$, but only Pass Hytten and Basalt Island during 2017 for logistical reasons. At each station, ten liters of seawater were collected at two depths corresponding to the surface (s-POM, $1 \mathrm{~m}$ below the surface) or bottom (b-POM, $1 \mathrm{~m}$ above the seabed), using two 51 Niskin bottles per sample. In parallel, SOM samples were collected at the sediment surface $\left(\approx 625 \mathrm{~cm}^{2}\right)$ by scuba divers using a $450 \mathrm{ml}$ syringe. Also, several individuals of $A$. moerchi and $M$. truncata were harvested either by scuba diving or using a triangular biological dredge (KC Denmark A/S) during both seasons.

130 In addition, three macroalgae species (Desmarestia aculeata, Fucus sp., and Saccharina 131 latissima) were harvested during summer in order to assess their potential contribution to the 
132 bivalves' diet. Statistical analyses were performed on our own results as well as some raw data

133 previously published in De Cesare (2016) and De Cesare et al. (2017) relating summer samples

134 of $A$. moerchi (SI signatures and FA profiles) and macroalgae (SI signatures).

\section{Analyses of Samples}

Preliminary treatments

POM samples were obtained by filtering collected water on precombusted GF/F Whatman® microfiber filters (diameter: $47 \mathrm{~mm}$, pore size: $0.7 \mu \mathrm{m}$ ) until clogging when possible (mean filtered volume $=7.9 \pm 1.9$ 1, range: $4-81$ ). Because syringe-collected samples comprise a mixture of SOM, inorganic particles, and seawater, we let the samples settle for one hour prior to filtering the supernatants until clogging on GF/F filters (mean volume $=0.260 \pm 0.100 \mathrm{ml}$, range: $100-450 \mathrm{ml}$ ) in order to remove most of inorganic sedimentary particles. In the field, all samples were directly frozen at $-80^{\circ} \mathrm{C}$ and transferred to the lab for further analyses. Once in the lab, all samples (i.e., POM and SOM filters as well as digestive glands and muscles) were freeze-dried at $-50^{\circ} \mathrm{C}$ for at least 5 hours (30 hours for animal tissues) and directly weighed. The POM and SOM filters were cut in two parts to perform both FA and SI analyses on the same sample. Each half-filter was weighed and the quantity of organic matter for the FA and SI analysis was calculated by the following equation:

$$
M(X)=\frac{W_{\text {Half filter }}}{W_{\text {Whole filter }}} X\left(W_{\text {Whole filter }}-W_{\text {Precombusted filter }}\right)
$$

Where M (X) is the mass (mg) of POM or SOM used for the FA or SI analysis and W is the dried weight of the half, whole, or precombusted filters.

\section{Fatty acids analysis}

The method used for the FA extraction largely follows the Bligh \& Dyer method (1959) as adjusted in Meziane \& Tsuchiya (2002). To quantify the FA concentrations, a known volume of a commercial standard (23:0, concentration of $5 \mathrm{mg} / \mathrm{ml})$ was introduced in each sample. Half- 
156 filters for POM and SOM analyses were diluted in a distilled water-chloroform-methanol

157 solution (1:1:2, v:v:v) and sonicated for 20 minutes for the FA extraction. The samples were

158 then completed by a distilled water-chloroform solution (1:1, v:v) and centrifuged (3000 rpm,

1595 minutes). Lipid phases were transferred to separate tubes, completed by a distilled water-

160 chloroform solution $(1: 1, \mathrm{v}: \mathrm{v})$, and sonicated again for 20 minutes to maximize the extraction.

161 Then, samples were evaporated under a dinitrogen $\left(\mathrm{N}_{2}\right)$ flux, diluted a second time in a mixture

162 of methanol and sodium hydroxide $\left(2: 1, \mathrm{v}: \mathrm{v} ;[\mathrm{NaOH}]=2\right.$ mol. $\left.{ }^{-1}\right)$, and heated at $90^{\circ} \mathrm{C}$ for 90

163 minutes for FA saponification. Finally, FAs were converted into FA methyl esters after

164 incubation for ten minutes at $90^{\circ} \mathrm{C}$ in a methanolic boron trifluoride solution $\left(\mathrm{BF}_{3}-\mathrm{CH}_{3} \mathrm{OH} 14 \%\right.$,

$1651 \mathrm{ml}$ ). At the end of the reaction, the chloroform phase containing FAs was retrieved and stored

166 at $-20^{\circ} \mathrm{C}$.

167 The FAs were quantified by gas chromatography (Varian CP-3800 equipped with a Supelco®

168 Omegawax ${ }^{\circledR}$ Capillary GC 320 column [length $=30 \mathrm{~m}$, inside diameter $=0.32 \mathrm{~mm}$, film

169 thickness $=0.25 \mu \mathrm{m}]$, He as carrier gas). FA pics were identified by comparing with those from

170 an analytical standard (Supelco® 37 Component FAME Mix) and confirmed by mass

171 spectrometry (Varian 220-MS coupled to a Varian 450-GC, He as carrier gas). FA

172 nomenclature is defined as $\mathrm{X}: \mathrm{Y} \omega \mathrm{Z}$, where $\mathrm{X}$ is the number of carbon atoms, $\mathrm{Y}$ is the number

173 of double bonds, and $\mathrm{Z}$ is the position of the last double bond from the methyl group. The 23:0

174 standard allowed converting each FA methyl esters area into a concentration using the

175 following equation (Schomburg 1987):

$$
C_{F A}=\left(\frac{A_{F A}}{A_{C 23}} \times \frac{C_{23}}{M_{f}}\right)
$$

177 where $\mathrm{C}_{\mathrm{FA}}$ is the FA concentration $(\mu \mathrm{g} / \mathrm{g}), \mathrm{A}_{\mathrm{FA}}$ is the FA peak area, $\mathrm{A}_{\mathrm{C} 23}$ is the 23:0 peak area,

$178 \mathrm{C}_{23}$ is the 23:0 quantity $(\mu \mathrm{g})$ added to each sample, and $\mathrm{M}_{\mathrm{f}}$ is the mass of matter deposited on

179 the analyzed half-filter. 
180

The analytical precision for the samples was generally less than $5 \%$ for the total amounts and major components of FA (Meziane pers. com.). Table 1 compiles all the FAs used as organic matter tracers in this study and their related biomarker information.

\section{Stable isotope analysis}

SI analysis was performed on the second half of each POM and SOM filter and on A. moerchi and $M$. truncata tissues. Half-filters were fumigated for at least four hours with $35 \% \mathrm{HCl}$ to remove inorganic carbon (Lorrain et al. 2003). The surface layer, including filtered POM (or SOM), was scraped and 10-30 mg of material was placed in tin capsules. Due to the small amounts of inorganic carbon in digestive glands and muscles, no acidification was performed with these tissues (Jacob et al. 2005, Søreide et al. 2006). The animal tissues were ground and approximately $1 \mathrm{mg}$ was placed in a single tin capsule for each sample. Macroalgae were ground and separated into two subsamples (De Cesare et al. 2017): one subsample was acidified (1M $\mathrm{HCl})$ to remove inorganic carbon and placed in silver capsules for $\delta^{13} \mathrm{C}$ analysis, while the second subsample was directly placed in tin capsules (without prior acidification) for $\delta^{15} \mathrm{~N}$ analysis.

All samples were analyzed at the University of California Davis Stable Isotope Facility (Department of Plant Sciences, UC Davis, Davis, California) by continuous flow isotope ratio mass spectrometry (CF-IRMS). The equipment consisted of an elemental analyzer (PDZ Europa ANCA-GSL [Sercon Ltd., Cheschire, UK] and Elementar Vario EL Cube elemental analyzer [Elementar Analysensysteme GmbH, Hanau, Germany] for animal tissue and filter analysis, respectively) interfaced to an isotope ratio mass spectrometer (PDZ Europa 20-20, Sercon Ltd., Cheschire, UK). Several replicates of laboratory standards, compositionally similar to analyzed samples and calibrated against NIST Standard Reference Materials (IAEA600, USGS-40, USGS-41, USGS-42, USGS-43, USGS-61, USGS-64, and USGS-65), were inserted between some of the filter and animal samples to correct deviations occurring during 
the analysis. The standard deviation of the stable isotope measurements was estimated to $\pm 0.2 \%$ o

206 for $\delta^{13} \mathrm{C}$ and $\pm 0.3 \%$ for $\delta^{15} \mathrm{~N}$ (UC Davis Stable Isotope facility pers. com.). Carbon and nitrogen

207 isotopic ratios were expressed in per mill (\%) and calculated from international standards

208 (Vienna Pee Dee Belemnite and Air, respectively) by the following equation:

$$
\delta X=\left[\left(\frac{R_{\text {sample }}}{R_{\text {standard }}}\right)-1\right] \times 1000
$$

where $\delta \mathrm{X}$ is $\delta^{13} \mathrm{C}$ or $\delta^{15} \mathrm{~N}$, and $\mathrm{R}$ is the corresponding ${ }^{13} \mathrm{C} /{ }^{12} \mathrm{C}$ or ${ }^{15} \mathrm{~N} /{ }^{14} \mathrm{~N}$ ratio (Peterson \& Fry 211 1987).

\section{Data analyses}

213 Since pelagic and benthic components usually show different organic matter sources and 214 qualities (e.g., Magen et al. 2010, Kuliński et al. 2014), we chose to separate the SOM and POM 215 samples for statistical analyses. Because our design was not balanced between the two seasons 216 (two stations sampled in winter vs. three in summer), we used two-way PERMANOVAs for each season to study the effects of depth (surface or bottom waters) and station factors on the FA profiles of POM. Since PERMANOVAs are not affected by small differences in dispersion, especially with a balanced design, the PERMDISP test was performed to ensure that data dispersion, possibly highly heterogeneous, would not disturb the interpretation of our analysis

221 (Anderson et al. 2008, Anderson \& Walsh 2013).

222 Seasonal differences in FA concentrations were tested by one-way ANOVA, whereas depth 223 and station effects were tested by two-way ANOVA for each season. FA concentrations were 224 log-transformed prior each analysis to validate normality and homoscedasticity assumptions. 225 When significant effects were detected, pairwise Tukey tests were used to determine if the differences were observed among all groups. Similar analyses were performed on carbon and

227 nitrogen isotopic ratios, with either 2 two-way ANOVAs (depth and stations as factors) or 1 228 one-way ANOVA (season as factor), as well as with pairwise tests if needed. 
Regarding FA data in animal tissues, homoscedasticity and normality were rarely observed

230 between the two factors (e.g., digestive glands from May vs. muscles from August). As data 231 transformation is not recommended for percentage values not derived from count data (as 232 percentage of lipids), we thus performed a one-way PERMANOVA to test each factor 233 separately (e.g., season was tested for each tissue from a single species). Data from the SI 234 analysis on animal tissue were treated similarly with one-way ANOVAs. All statistical analyses 235 were performed using R software (R Core Team 2017).

RESULTS

$$
\text { Particulate Organic Matter (POM) }
$$

Sixty-five FAs were identified in POM and SOM samples (44 FAs in August and 47 in May).

Only FA percentages higher than $0.2 \%$ in at least one sample are shown in Table 2. Strong seasonal differences were observed in the FA profiles of the POM samples. For example, apart from s-POM from Basalt Island, the total percentage of PUFAs was between 9.7\% and $22.1 \%$ in August and was always less than $1.5 \%$ in May. Concomitantly, the sum of saturated FAs $(\Sigma$ 244 SFA) shows opposite seasonal variations, with higher values in May (range: 82.5\%-93.1\%) compared to August (range: 49.5\%-69.3\%).

In August, the FA profiles of the POM samples differed significantly depending on site and 247 depth (p-value < 0.01) and without any interaction between these factors (Table 3). The depth 248 variations in the POM FA profiles were not similar between stations. In fact, the FA profiles of 249 s-POM and b-POM samples from Pass Hytten were rather similar (similarity = 73.1\%), but 250 those from Basalt Island differed more with depth (e.g., 18:1 $1 \omega 9=1.9 \%$ and $6.2 \%$ for s-POM 251 and b-POM, respectively; Table 2). In samples from Kap Breusing, the FA profiles strongly 252 differed between surface and bottom waters (similarity $=64.2 \%$ ) with 20:5 $\omega 3$ percentages 
253

254

255

256

higher in b-POM than in s-POM (9\% vs. $2.7 \%$, respectively, Table 2). Considering spatial variability, FA profiles related to the s-POM from Basalt Island in August (Table 2) revealed much more degraded organic matter compared to those from other stations, with a higher sum of SFAs (84.4\%), a lower sum of PUFAs (3.1\%), and a much lower FA concentration (2.6 mg.g - $^{-}$ $\left.{ }^{1}\right)$ than in Pass Hytten and Kap Breusing (8.0 and 9.4 mg. $\mathrm{g}^{-1}$ respectively; pairwise test: p-value $<0.001)$. In contrast, the b-POM samples were rather similar between Basalt Island and Pass Hytten, while those from Kap Breusing had a distinct FA composition, with high PUFA and monounsaturated FA (MUFA) proportions (22.1\% and 25.6\% respectively, Table 2). This was

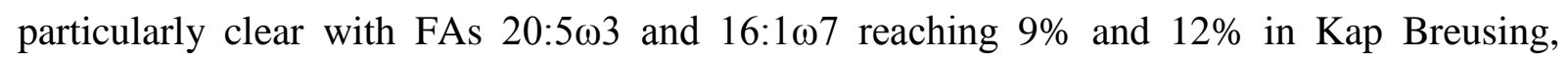
respectively, whereas they were less than $3.7 \%$ and $6.9 \%$ at the other two sites, respectively (Table 2). However, we did not observe any difference in FA concentration among stations (pvalue $>0.05$ ).

In May, the FA profiles differed significantly according to both site and depth ( $\mathrm{p}$-value $<0.05$; Table 2) without any interaction between these two factors ( $p$-value $=0.077$ ). At both stations, POM appeared to be slightly more degraded in surface vs. bottom waters, as shown by the higher proportion of SFAs in s-POM (Table 2). Considering spatial variability, a higher proportion of $\Sigma$ SFA was observed in Pass Hytten than in Basalt Island (93.1 vs. 88.4 for sPOM and 90.4 vs. 82.5 for b-POM, respectively; Table 2). However, such depth and station differences were relatively weak, as attested by the strong similarity between the s-POM and b-POM ( $84.7 \%$ similarity) as well as the Basalt Island and Pass Hytten samples $(81.7 \%$ similarity).

\section{Sedimentary Organic Matter}

SOM exhibited strong seasonal differences with much higher proportions of SFAs in May; yet, these FAs represented only the half of the summer composition ( $\Sigma$ SFA $=92.2 \%$ vs. $56.9 \%$ for winter and summer, respectively). Similarly, only some traces of PUFAs were detected in May 
while their proportion reached $12.9 \%$ in August (Table 2). Summer PUFA and MUFA

279 proportions were mainly linked to $20: 5 \omega 3$ and $16: 1 \omega 7$ contributions $(18.3 \%$ and $6.2 \%$,

280 respectively; Table 2). Strong seasonal differences were also observed in the FA concentrations,

281 which were three-fold more abundant during August (0.7 vs. 0.2 for August and May, 282 respectively, Table 2). In contrast with the POM samples, no differences among stations were 283 observed in SOM during August ( $\mathrm{p}$-value $=0.066)$ and May (p-value $=0.168)$.

\section{Stable isotopes of POM and SOM samples}

285

In August, depth appeared to be the first discriminating factor in $\delta^{13} \mathrm{C}$ and $\delta^{15} \mathrm{~N}$ values among the POM samples. At each station, these $\delta^{13} \mathrm{C}$ and $\delta^{15} \mathrm{~N}$ values differed significantly between surface and bottom waters ( $\mathrm{p}$-value $<0.0001$ ), with overall more enriched values by $1 \%$ o for $\delta^{13} \mathrm{C}$ and $2 \%$ for $\delta^{15} \mathrm{~N}$ in b-POM (Fig. 2). Globally, the isotopic signatures were closer between samples for the surface compared to the bottom stations. Moreover, no significant differences were observed between s-POM samples from Kap Breusing and Pass Hytten (for both $\delta^{13} \mathrm{C}$ and $\delta^{15} \mathrm{~N}$ values) and between b-POM samples from Pass Hytten and Kap Breusing (only for $\delta^{15} \mathrm{~N}$ values, p-value >0.05).

In contrast, all isotopic ratios associated with the May samples increased an average of $1.2 \%$ and $2.4 \%$ for $\delta^{13} \mathrm{C}$ and $\delta^{15} \mathrm{~N}$, respectively. These ratios did not vary significantly with depth within each station (p-value > 0.05, Fig. 2), but for both s-POM and b-POM, they differed significantly between stations (p-value $<0.05$, Fig. 2 ).

During summer, mean $\mathrm{SOM} \delta^{13} \mathrm{C}$ levels were more enriched, by $2.7 \%$ and $1.6 \%$, when compared to s-POM and b-POM, respectively (Fig. 2). Spatial differences were also observed during this season, but they were not significant between Pass Hytten and Basalt Island for $\delta^{13} \mathrm{C}$ values and between Basalt Island and Kap Breusing for $\delta^{15} \mathrm{~N}$ values (pairwise test: p-value > 0.05). During May, the $\delta^{13} \mathrm{C}$ level did not differ between Pass Hytten and Basalt Island (p-value $=0.197)$, and this level was also similar to that from August $(-24.7 \%$ in average for SOM from 
303 Pass Hytten and Basalt Island during both seasons, p-value > 0.05, Fig. 2). $\delta^{15} \mathrm{~N}$ values differed 304 significantly between Pass Hytten and Basalt Island ( $p$-value $<0.001)$ and increased when compared to August levels by $0.9 \%$ and $2.6 \%$ for Pass Hytten and Basalt Island, respectively 306 (Fig. 2).

\section{Fatty acids profiles and isotopes values of bivalves}

Fatty acids

FA signatures associated with the muscle and digestive gland samples of $M$. truncata differed between seasons (p-value $<0.01$, Tables 3 and 4). For the muscle samples, such differences

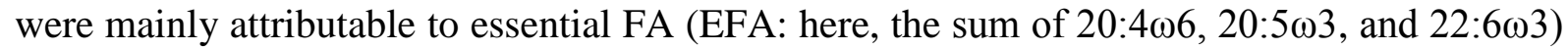
variations (41.7\% vs. 35.1\% for August and May, respectively; Table 4). Temporal differences in the digestive gland data were especially obvious for the 20:5 $03 / 22: 6 \omega 3$ ratio (14.5 vs. 1.3 in August and May, respectively; Table 4) and for 16:1 1 7 (22.5\% vs. 3.4\% in August and May, respectively; Table 4). Interestingly, although FA profiles of muscles differed from those of 316 digestives glands during August ( $\mathrm{p}$-value $<0.01$, Table 5), they were not statistically different 317 during May $(\mathrm{p}$-value $=0.322$, Table 5).

318 For $A$. moerchi tissues, both muscles and digestive glands had distinct FA profiles between 319 seasons ( $\mathrm{p}$-value $<0.001$, Table 5). The highest PUFA and EFA percentages for digestive 320 glands were found in May (Table 4). In contrast, MUFAs were dominant during August, mainly 321 due to twice higher values of 16:1w7 compared to May (Table 4). A similar trend was observed 322 for muscle FA profiles, with May contributions of EFA and PUFA double those of August (e.g.,

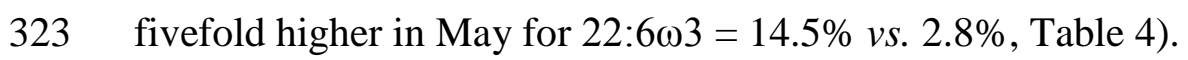

\section{Isotopes}

Although isotopic signatures of the digestive glands of $A$. moerchi $\left(\delta^{13} \mathrm{C}=-24.2 \%\right.$ and $\delta^{15} \mathrm{~N}=$ 
were more distinct in May (Fig. 3). In fact, seasonal differences for $\delta^{13} \mathrm{C}$ and $\delta^{15} \mathrm{~N}$ were observed in M. truncata $\left(+3 \%\right.$ and $+1.5 \%$ between August and May for $\delta^{13} \mathrm{C}$ and $\delta^{15} \mathrm{~N}$ [p-value $<0.05$ ], respectively, Fig. 3) but not in A. moerchi (+0.4\%o and $-0.2 \%$ between August and May for $\delta^{13} \mathrm{C}$ and $\delta^{15} \mathrm{~N}$ [p-value > 0.05], respectively, Fig. 3). Regarding muscle tissues, no seasonal variations of $\delta^{13} \mathrm{C}$ and $\delta^{15} \mathrm{~N}$ were observed in either species (Fig. 3), and no inter-specific variations were observed during each season ( $p$-value $>0.05)$.

In May, carbon and nitrogen isotopic values of s-POM, b-POM, and macroalgae samples clearly differed from those of digestive gland and muscle tissues in both bivalves (Fig. 3B). In contrast, isotopic values of $A$. moerchi and $M$. truncata became closer in summertime to POM and SOM values (Fig. 3A).

\section{DISCUSSION}

\section{Influences of seasonal and spatial constraints on the POM and SOM patterns}

Seasonal patterns

There have been few studies of the seasonal variability between ice cover and open sea periods in the main pelagic and benthic food sources of bivalves in High Arctic coastal areas (but see Connelly et al. 2015, Connelly et al. 2016). This work constitutes the first contribution for the Young Sound fjord. During the productive summer period, FA composition of the POM in bottom waters revealed the dominant contribution of several photosynthetic producers, such as diatoms $(16: 1 \omega 7,20: 5 \omega 3)$, dinoflagellates $(18: 4 \omega 3,22: 6 \omega 3)$, and macroalgae $(18: 2 \omega 6,18: 3 \omega 3$,

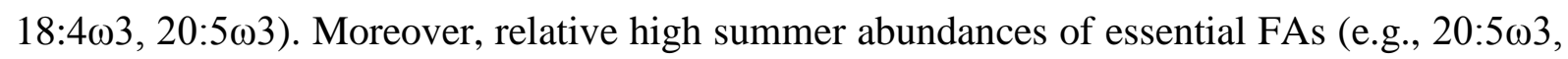
$22: 6 \omega 3,18: 4 \omega 3)$ in animals and bivalves contrast with the winter situation. In winter, with the absence of in situ primary production, POM was highly degraded; this was reflected by the large proportion of total SFA (Rhead et al. 1971, Connelly et al. 2015, Connelly et al. 2016). Very low levels of total PUFAs during May (i.e., $<1.5 \%)$ indicate that the extended duration of 
ice and snow cover in Young Sound is paired to the absence of fresh organic matter for primary

352 consumers compared to other Arctic fjords (e.g., $\Sigma$ PUFA $=14.3 \%-39.8 \%$ in Kongsfjorden,

353 13.4\% in Rijpfjorden; Leu et al. 2006, Leu et al. 2011). In fact, in May after 4-5 months in

354 darkness, the POM lipid concentrations measured in Young Sound (2.6-11.3 mg/g) are much 355 lower than in any other Arctic fjord (for example, $95.4-98.6 \mathrm{mg} / \mathrm{g}$ in Kobbefjord; Gaillard et 356 al. 2017). In May, despite 24-hour daylight, the presence of snow on the sea ice prevents the 357 transmission of light (Glud et al. 2007), and primary production does not start before mid-July 358 when melt-water ponds that form on the sea ice intensifies light transmission. This in turn 359 triggers a short algal bloom (Rysgaard et al. 1999). PAR sensors fixed at $1 \mathrm{~m}$ depth below the 360 sea ice revealed no available PAR for primary producers in May (Mikael Sejr, unpublished 361 data). For SOM, seasonal changes in FA composition show the same trends as in May POM, 362 as shown by low FA and total PUFA concentrations. In contrast, diatoms dominate the SOM 363 during the summer, as revealed by higher relative proportions of $16: 1 \omega 7$ and 20:5 13 , whereas 364 dinoflagellates $(18: 4 \omega 3,22: 6 \omega 3)$ and macroalgae markers $(18: 2 \omega 6,18: 3 \omega 3,20: 4 \omega 6,20: 5 \omega 3)$ 365 suggest additional contributions of these primary sources to the pool of organic matter.

366 The absence of significant primary production in May is confirmed by a general increase in 367 $\delta^{15} \mathrm{~N}$ in both POM and SOM. Indeed, food webs from sea ice-covered ecosystems switch to heterotrophy during the polar night due to the development of protozoans and/or microbial planktonic communities (Berge et al. 2015). As heterotrophic microorganisms may be 370 consumers of organic matter, their isotopic signatures should be enriched in $\delta^{15} \mathrm{~N}$ when 371 compared to autotrophic algae (Hoch et al. 1996, Tamelander et al. 2009). Hence, such $\delta^{15} \mathrm{~N}$ enrichment could explain the seasonal increase of the $\delta^{15} \mathrm{~N}$ in POM during winter (Tamelander

373 et al. 2009, Kẹdra et al. 2012), but it also may reflect the increased contribution of animal 374 detritus and fecal pellets (Sampei et al. 2012) and diagenesis (Schulz \& Zabel 2006). 
The Marine Basis monitoring program has conducted annual surveys in August since 2003 that

377 documented the strong influence of terrestrial runoff on the water column, especially in surface waters (above $10 \mathrm{~m}$ depth), as attested by lower salinity and higher turbidity measurements (Citterio et al. 2017, Middelbo et al. 2018). This influence of direct freshwater inputs is confirmed by s-POM $\delta^{15} \mathrm{~N}$ values $\left(4.2 \pm 0.3 \%\right.$, which are almost identical with riverine $\delta^{15} \mathrm{~N}$ values (4.3 \pm 0.3\%o, Zackenberg River, Rysgaard \& Sejr 2007). Poorer organic matter quality in s-POM compared to b-POM (as expressed by the high levels of $\Sigma$ SFA and low levels of $\Sigma$ PUFA) suggests an increase in the relative proportion of detrital particles compared to living cells in surface waters (Leu et al. 2006, Mayzaud et al. 2013). Such observations are likely explained by the inflow of nutrient-depleted freshwater (confined to surface waters), which may both discharge a huge amount of terrestrial detrital particles and decrease primary productivity 387 (Mayzaud et al. 2013, Meire et al. 2016, Meire et al. 2017). This hypothesis is consistent with 388 previous findings in Young Sound, which showed lower chlorophyll- $a$ concentrations in the most runoff-exposed parts of the fjord (Meire et al. 2016, Arendt et al. 2016, Middelbo et al. 2018).

391 Overall, POM from Young Sound bottom waters was nutritionally richer than that from surface 392 waters, as reflected by higher proportions of EFA. However, the related $\delta^{13} \mathrm{C}$ and $\delta^{15} \mathrm{~N}$ values were highly variable among the stations, and we hypothesize that this could be attributable to 394 their differential exposure to freshwater inputs. Thus, higher $\delta^{13} \mathrm{C}$ and $\delta^{15} \mathrm{~N}$ found in b-POM in 395 Pass Hytten and Basalt Island could be explained by greater exposure of inner fjord waters to 396 nutrient-depleted and $\mathrm{CO}_{2}$-desaturated freshwater inputs (Tamelander et al. 2009, Meire et al. 397 2015, Meire et al. 2016). It also possibly indicates more degraded organic matter at the inner 398 stations due to higher bacterial activity (McTigue et al. 2015). These spatial SI discrepancies 399 may also reflect different bloom dynamics (duration, kinetics) among stations, since isotopic 400 signatures generally show an enrichment during a bloom (Savoye et al. 2003, Tamelander et al. 
401

402

403

404

405

406

407

408

409

410

411

412

413

414

415

416

417

418

420

421

424

425

2009). In addition, the higher percentages of diatom and dinoflagellate markers (see above details) in Kap Breusing may reflect local primary productivity that is higher in the outer than in the inner part of the fjord. Accordingly, Meire et al. (2016) showed that upwelling of nitrate and phosphate-rich waters around the fjord's mouth sustains a high phytoplankton biomass throughout the summer.

Identifying and quantifying the sources of organic matter in superficial marine sediments is a difficult task, as terrestrial inputs, benthic primary producers (including microphytobenthos and macroalgae), and sedimentation of POM may all be present. For instance, SOM quality and quantity may be affected by benthic organisms through bioturbation, burrowing, use of organic matter, and excretion (e.g., Glud et al. 2000). Although FA analysis results show an input of macroalgae to the SOM, their contributions should be rather limited. Indeed, previous compound-specific isotopic analyses excluded the contribution of Desmarestia aculeata to the pelagic and benthic pool of organic matter (De Cesare et al. 2017, Bridier's unpublished data). In addition, the Fucus sp. and Saccharina latissima contributions seem relatively weak, as $\delta^{13} \mathrm{C}$ values of both species $(19.2 \pm 2.2 \%$ and $-21.1 \pm 0.0 \%$, respectively) strongly differ from the SOM $\delta^{13} \mathrm{C}$ value $(-24.9 \pm 0.6 \%)$. According to published $\delta^{13} \mathrm{C}$ signatures of Arctic microphytobenthos (from $-23.9 \%$ to $-20.0 \%$; Oxtoby et al. 2016), riverine POM (-25.6 $\pm 0.1 \%$, Zackenberg River; Rysgaard \& Sejr 2007), and b-POM measured in the present study (-26.5 \pm $0.6 \%$ ), the $\mathrm{SOM} \delta^{13} \mathrm{C}$ values probably reflect either (1) a strong contribution of terrestrial organic matter associated with a minor contribution of microphytobenthos, or (2) an equal contribution of marine b-POM and microphytobenthos to SOM. According to the $\mathrm{C} / \mathrm{N}$ ratios calculated from the Young Sound $(18.3 \pm 1.7,10.3 \pm 0.2$, and $9.1 \pm 0.2$ for the SOM of Pass Hytten, Basalt Island, and Kap Breusing, respectively) and riverine data $(10<\mathrm{C} / \mathrm{N}$ ratio $<40$, Zackenberg river; Rysgaard \& Sejr 2007), the FA composition of Kap Breusing sediment should be less influenced by terrestrial inputs than the other two sites. Moreover, FA profiles 
of Kap Breusing and Basalt Island sediments display the highest percentages of diatom markers $(16: 1 \omega 7,16: 4 \omega 1$, and $20: 5 \omega 3)$, strongly suggesting that the associated SOM originates from both microphytobenthos and sedimented phytoplankton (second scenario). In contrast, sediments from Pass Hytten should receive organic matter from dominant terrestrial inputs with a low contribution from marine primary producers (first scenario).

431 Comparing marine and riverine POM and SOM $\delta^{13} \mathrm{C}$ values, Rysgaard \& Sejr (2007) estimated 432 that half of the Young Sound's sediment organic carbon came from terrestrial sources. 433 However, the marine $\mathrm{POM} \delta^{13} \mathrm{C}$ value $(-21.6 \pm 0.3 \%$ ) used for their estimate originates from a 434 study conducted by Hobson \& Welch (1992) in Barrow Strait (NE Canada) that differs from 435 those found here (-26.5 $\pm 0.6 \%$, present study; $-25.5 \pm 0.1 \%$; De Cesare et al. 2017). Although 436 Young Sound's POM $\delta^{13} \mathrm{C}$ isotopic ratios may vary across years, multiannual values relative to 437 a site close to Ny-Ålesund (Kongsfjorden, Svalbard) during May vary slightly between 2007, 4382012 , and $2013(-21.6 \pm 0.2 \%$, $-22.7 \%$, and $-23.1 \pm 0.4 \%$, respectively; Renaud et al. 2011, 439 De Cesare 2016, Calleja et al. 2017). We therefore suggest that differences in POM $\delta^{13} \mathrm{C}$ values

440 between Young Sound and Barrow Strait do not depend on temporal variations, and that future 441 work on the contribution of terrestrial organic matter to SOM should be based on local POM $442 \quad \delta^{13} \mathrm{C}$ values.

\section{Diet of Astarte moerchi and Mya truncata}

444 Since sampling of bivalves was conducted over two different years, the seasonal comparison of 445 FA profiles and SI signatures probably reflects both seasonal and interannual variabilities of 446 their food sources. However, as the FA profiles of arctic bivalves are usually more sensitive to 447 seasonality than interannual variability (e.g., Birkely et al. 2003), we are confident that the FA 448 profiles from a specific origin and season will be quite stable between years. Moreover, because 449 of the huge seasonality of the Young Sound's physical environment and carbon transport 450 (Rysgaard et al. 2003), the bivalves' food sources should also display much higher seasonal 
than interannual variations. In contrast, it is more difficult to distinguish seasonal from interannual variability in bivalves' SI signatures, since they vary minimally between seasons and years (Renaud et al. 2011, Kędra et al. 2012, McTigue \& Dunton 2014, Gaillard et al. 2017). Thus, seasonal differences in bivalves' SI signatures should be interpreted with caution.

Usually, FA associated with neutral lipids (used as energy storage) is directly mobilized from the diet, while polar FA (cell membrane components) is subjected to strong physiological regulation (Jezyk \& Penicnak 1966, Napolitano \& Ackman 1992, Pazos et al. 2003, Gaillard et al. 2015). Since the digestive gland has a lipid storage function, this tissue displays high levels of neutral compared to polar lipids. In contrast, muscle tissue contains low levels of neutral and thus higher proportions of polar lipids (Napolitano \& Ackman 1992, Pazos et al. 2003). For that reason, digestive glands usually have a higher lipid turnover rate and diet sensitivity, whereas muscles are more sensitive to physiological regulation (Napolitano \& Ackman 1992, Napolitano et al. 1997, Nérot et al. 2015). Such inter-tissue differences were also evident in the

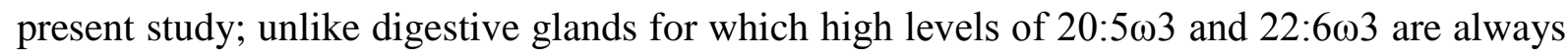
associated with high levels of diatoms or dinoflagellates dietary FA markers, these two FAs were not associated with high levels of their dietary FA markers in muscle. Therefore, the

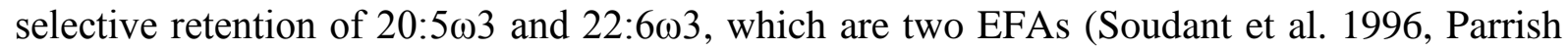
2009), confirms that muscle and digestive glands may constitute real proxies of bivalves' diet and physiological conditions, respectively.

During summer, the FA compositions and isotopic signatures of the digestive glands of $A$. moerchi and $M$. truncata were very similar. This suggests that both bivalves have the same diet dominated by diatoms, as shown by the high proportions of $16: 1 \omega 7$ and $20: 5 \omega 3$, which are also found in POM and SOM during summer (De Cesare et al. 2017). Such strong similarities in FA profiles between bivalves and their food sources indicate tight benthic-pelagic coupling as well as an efficient organic matter transfer from primary producers to primary consumers in the 
Young Sound food web. If we consider the summer FA composition of muscles, both species

477

478

479

480

481

482

483

484

485

486

487

488

489

490

491

492

493

494

495

496

497

498

499

500 exhibit rather good physiological states as indicated by high levels of EFAs, as these are essential for somatic growth, reproduction, and the maintenance of cell membrane fluidity (Soudant et al. 1996, Parrish 2009).

During winter, $\delta^{13} \mathrm{C}$ values associated with POM, SOM, and macroalgae sources were too distinct from those of digestive glands and muscles, thus these sources were unlikely to contribute to the bivalves' diet. Although macroalgae $\delta^{13} \mathrm{C}$ values may slightly fluctuate between seasons (Vizzini \& Mazzola 2003), the lack of macroalgal FA markers in bivalve tissues provides evidence that macroalgae were not consumed during winter. We thus suggest that poor trophic environmental winter conditions, evidenced by highly degraded organic matter sources, induce a drastic decrease and more likely an interruption in the feeding activity of both bivalves. Such winter quiescence has previously been observed in bivalves (Pernet et al. 2007, Comeau et al. 2012) but contrasts with numerous studies reporting the persistence of long-term "food banks" in polar benthic ecosystems (e.g., Mincks et al. 2005) that fuel many organisms by labile detritus (McClintock 1994, Mincks et al. 2008, McMeans et al. 2015, Silberberger et al. 2018). This is not the case in Young Sound fjord, where the survival of $A$. moerchi and $M$. truncata individuals relates to their reliance on energetic reserves under a poor trophic winter environment. Moreover, each species displays a distinct pattern in its ability to use these lipids. Hence, the similar FA profiles observed during winter between digestive glands and muscle tissues of $M$. truncata may reflect a depletion of its lipid reserves. This phenomenon will induce a decrease in the concentration of neutral lipids (constituent of the lipid reserves in digestive glands) and will mechanically increase the proportion of polar lipids in this tissue (i.e., there will be a higher proportion of polar lipids in winter for a similar concentration between the two seasons). Hence, the similar lipid class composition between digestive glands and muscles may increase the similarity in their lipid profiles. The seasonal increase of digestive 
501 gland $\delta^{13} \mathrm{C}$ values may strengthen this hypothesis, since lipids are more depleted in $\delta^{13} \mathrm{C}$ than 502 in other compounds (Lorrain et al. 2002). The increase in $\delta^{13} \mathrm{C}$ and $\delta^{15} \mathrm{~N}$ may also reflect the 503 impact of starvation on M. truncata metabolism (Hertz et al. 2015, Doi et al. 2017). A

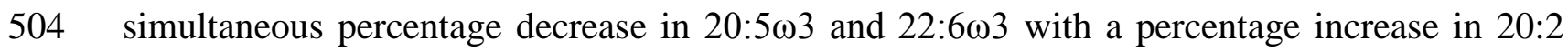
505 NMI (non-methylene-interrupted) FA also confirms the poor physiological state of $M$. truncata 506 during winter. In fact, NMI biosynthesis should be critical for this species for maintaining both 507 structure and fluidity of their cell membranes in the face of a decrease in PUFA levels (Pernet 508 et al. 2007, Gaillard et al. 2015). The lipid reserves were less depleted in winter for A. moerchi 509 than M. truncata. In fact, the winter FA concentration in digestive glands for A. moerchi was 510 twice as high as for M. truncata, and the proportions of EFA and FA trophic markers remain 511 high compared to those in summer. Such species-specific seasonal patterns of lipid reserves 512 could be explained by (1) differential lipid mobilization during winter, or (2) the differential ability to build lipid reserves during the rise in primary production. Data from the present study

514 do not support one hypothesis over the other. For instance, the first hypothesis may reflect the 515 bivalves' ability to reduce their metabolic rate or their reproduction investment. However, both 516 species show a similar decrease in their $\omega 3 / \omega 6$ ratio during winter, which may indicate that they 517 devote similar efforts to reproduction (Leroy et al. 2013, De Cesare 2016). Likewise, little 518 information is available about their ability to reduce their metabolic rate during starvation or 519 any other physiological stress (e.g., Abele-Oeschger \& Oeschger 1995, Camus et al. 2003). 520 Hence, further studies, such as in situ measurements of bivalve metabolic rate or clearance rates 521 during winter or observations about their ability to store lipid during a short food supply (e.g., 522 as for Yoldia hyperborea; Stead et al. 2013), will be thus helpful to better explore such 523 hypotheses.

524 Finally, about 30\% of Young Sound's seafloor is below $100 \mathrm{~m}$ depth (Rysgaard et al. 2003), 525 and the link between filter feeders and primary producers in deeper basins may differ from our 
results from shallow areas. Although vertical carbon fluxes at both shallow and deeper depths

527 have not been quantified in this fjord, the very low abundance of benthic macrofauna at $85 \mathrm{~m}$ depth (Glud et al. 2000, Sejr et al. 2000) suggests a decrease in carbon transfer to deeper areas via pelagic-benthic coupling (Ambrose \& Renaud 1995). However, because similar C/N ratios were found at 20 and $163 \mathrm{~m}$ depth (Glud et al. 2000), we hypothesize that organic matter transfer

531 from the surface to deeper basins would be fast enough to fuel benthic filter-feeding species 532 with relatively fresh organic matter (i.e., similar to that in shallow waters). Such tight pelagic533 benthic coupling has previously been reported up to $600 \mathrm{~m}$ depth in the High Arctic Canadian 534 archipelago for the filter-feeding bivalve Bathyarca glacialis (Gaillard et al. 2015).

\section{Conclusion and outlooks}

536 Extremely long sea-ice cover deprives Young Sound of fresh primary production during most of the year, while freshwater inputs strongly degrade the quality of organic matter in surface waters and seems to control the primary production dynamics within bottom waters during summer. However, distinct adaptations are observed among filter-feeding bivalves to cope with

540 the long winter conditions: A. moerchi seems to be best adapted to live on stored energy 541 reserves, whereas the depletion of $M$. truncata's lipid reserves during May suggest it has less energetic margin to survive the winter.

543 In the face of climate change, Young Sound will be exposed to a continued freshening of its

544 surface water masses, preventing the renewal of deeper basin water masses in the inner fjord 545 (e.g., Sejr et al. 2017, Boone et al. 2018). Numerous studies have highlighted the effect of such 546 a freshening on the Young Sound's primary productivity through a decrease in light (Murray et 547 al. 2015) and nutrient availability (Meire et al. 2016). Results from our study suggest that this 548 decrease in primary productivity may be amplified by a decrease in organic matter quality in 549 the inner parts of this fjord. In contrast, the outer part of Young Sound may be less affected by 550 this freshening due to its sill, which allows nutrient replenishment through vertical mixing 
551 (Meire et al. 2016). However, such impoverishment of the trophic environment in the inner

552 fjord may weaken the ability of some primary consumers (e.g., Mya truncata) to accumulate 553 enough lipid reserves during summer to cope with winter conditions, and this might have 554 cascading effects on their survival and renewal potential. Considering the key functional role 555 of such filter-feeding bivalves for the transfer of organic matter toward higher trophic levels, 556 such a shift could impact the entire benthic food web from primary producers to mammals, 557 especially walrus that can consume up to $57 \mathrm{~kg}$ of fresh Mya truncata per day (Born et al. 2003).

\section{ACKNOWLEDGEMENT}

559 We are grateful to Erwan Amice for his difficult work in collecting bivalves and SOM samples 560 while scuba diving. We greatly thank Najet Thiney for her valuable help in the laboratory of 561 the Muséum National d'Histoire Naturelle (MNHN, Paris). Many thanks to S. De Cesare for 562 sharing row data from De Cesare et al. (2017) and De Cesare (2016). We are grateful to the 563 Université de Bretagne Occidentale/LIA BeBEST and the "Allocations de recherche doctorale" 564 from the Brittany Region Council for co-funding the $\mathrm{PhD}$ thesis of $\mathrm{G}$. Bridier. We would like 565 to acknowledge the support of the MarineBasis programme (part of the Greenland Ecosystem 566 Monitoring) and of Zackenberg staff during the surveys, especially Egon Randa Fransen and 567 Henrik Spenggaard Munch. Two anonymous reviewers are thanked for their English 568 corrections and relevant remarks, which greatly improved this manuscript. 


\section{REFERENCES}

Abele-Oeschger D, Oeschger R (1995) Hypoxia-induced autoxidation of haemoglobin in the benthic invertebrates Arenicola marina (Polychaeta) and Astarte borealis (Bivalvia) and the possible effects of sulphide. J Exp Mar Biol Ecol, 187:63-80

AMAP (2017) Snow, water, ice and permafrost in the Arctic (SWIPA). Artic Monitoring and Assessment Programme (AMAP), Oslo, Norway

Ambrose WG, Renaud PE (1995) Benthic response to water column productivity patterns: evidence for benthic-pelagic coupling in the Northeast Water Polynya. J Geophys Res $100: 4411-4421$

Anderson MJ, Gorley RN, Clarke KR (2008) PERMANOVA+ for PRIMER: Guide to Software and Statistical Methods. Primer-E, Plymouth

Anderson MJ, Walsh, DC (2013) PERMANOVA, ANOSIM, and the Mantel test in the face of heterogeneous dispersions: what null hypothesis are you testing? Ecol monogr 83:557574

Ardyna M, Babin M, Gosselin M, Devred E, Rainville L, Rainville L, Tremblay JÉ (2014) Recent Arctic Ocean sea ice loss triggers novel fall phytoplankton blooms. Geophys Res Lett 41:6207-6212

Arendt KE, Agersted MD, Sejr MK, Juul-Pedersen T (2016) Glacial meltwater influences on plankton community structure and the importance of top-down control (of primary production) in a NE Greenland fjord. Estuar Coast Shelf Sci 183:123-135

Arimitsu ML, Piatt JF, Mueter F (2016) Influence of glacier runoff on ecosystem structure in Gulf of Alaska fjords. Mar Ecol Prog Ser 560:19-40 
Arrigo KR, van Dijken GL (2015) Continued increases in Arctic Ocean primary production. Prog Oceanogr 136:60-70

Bamber J, van den Broeke M, Ettema J, Lenaerts J, Rignot E (2012) Recent large increases in freshwater fluxes from Greenland into the North Atlantic. Geophys Res Lett 39:L19501

Bendtsen J, Gustafsson K, Rysgaard S, Vang T (2007) Physical conditions, dynamics and model simulations during the ice-free period of the Young Sound/Tyrolerfjord system. Medd Grønland Biosci 58:45-59

Bendtsen J, Mortensen J, Rysgaard S (2014) Seasonal surface layer dynamics and sensitivity to runoff in a high Arctic fjord (Young Sound/Tyrolerfjord, $74^{\circ} \mathrm{N}$ ). J Geophys Res Oceans 119:6461-6478

Berge J, Renaud PE, Darnis G, Cottier F, Last K, Gabrielsen TM, Johnsen G, Seuthe L, Weslawski JM, Leu E, Moline M, Nahrgang J, Søreide JE, Øystein V, Lønne JO, Daase M, Falk-Petersen S (2015) In the dark: a review of ecosystem processes during the Arctic polar night. Prog Oceanogr 139:258-271

Birkely SR, Grahl-Nielsen O, Gulliksen B (2003) Temporal variations and anatomical distributions of fatty acids in the bivalve Mya truncata, L. 1758, from Isfjorden, Spitsbergen. Polar Biol 26:83-92

Bligh EG, Dyer WJ (1959) A rapid method of total lipid extraction and purification. Can J Biochem Physiol 37:911-917

Boone W, Rysgaard S, Carlson DF, Meire L, Kirillov S, Mortensen J, Dmitrenko I, Vergeynst L, Sejr MK (2018) Coastal freshening prevents fjord bottom water renewal in Northeast Greenland: A mooring study from 2003 to 2015. Geophys Res Lett 45:2726-2733 
614 Born EW, Rysgaard S, Ehlmé G, Sejr M, Acquarone M, Levermann N (2003) Underwater observations of foraging freeliving Atlantic walruses (Odobenus rosmarus rosmarus) and estimates of their food consumption. Polar Biol 26:348-357

Calleja ML, Kerhervé P, Bourgeois S, Kędra M, Leynaert A, Devred E, Babin M, Morata N (2017) Effects of increase glacier discharge on phytoplankton bloom dynamics and pelagic geochemistry in a high Arctic fjord. Prog Oceanogr 159:195-210

Camus L, Birkely SR, Jones MB, Børseth JF, Grøsvik BE, Gulliksen B, Lønne OJ, Regoli F, Depledge MH (2003) Biomarker responses and PAH uptake in Mya truncata following exposure to oil-contaminated sediment in an Arctic fjord (Svalbard). Sci Total Environ,

Carmack E, Winsor P, Williams W (2015) The contiguous panarctic Riverine Coastal Domain: A unifying concept. Prog Oceanogr 139:13-23

Citterio M, Sejr MK, Langen PL, Mottram RH, Abermann J, Larsen SH, Skov K, Lund M 627 (2017) Towards quantifying the glacial runoff signal in the freshwater input to Tyrolerfjord-Young Sound, NE Greenland. Ambio 46:146-159

Comeau LA, Mayrand É, Mallet A (2012) Winter quiescence and spring awakening of the Eastern oyster Crassostrea virginica at its northernmost distribution limit. Mar Biol in quantity and composition of suspended particulate organic matter in lagoons of the Alaskan Beaufort Sea. Mar Ecol Prog Ser 527:31-45 
635 Connelly TL, Businski TN, Deibel D, Parrish CC, Trela P (2016) Annual cycle and spatial trends in fatty acid composition of suspended particulate organic matter across the Beaufort Sea shelf. Estuar Coast Shelf Sci 181:170-181

Dalsgaard J, John MS, Kattner G, Müller-Navarra D, Hagen W (2003) Fatty acid trophic markers in the pelagic marine environment. Adv Mar Biol 46:225-340

De Cesare (2016) Les bivalves filtreurs Astarte moerchi : modèle biologique pour l'étude des écosystèmes marins arctiques. PhD dissertation, Muséum National d'Histoire Naturelle, Paris, France. https://tel.archives-ouvertes.fr/tel-01884169

De Cesare S, Meziane T, Chauvaud L, Richard J, Sejr MK, Thébault J, Winkler G, Olivier F (2017) Dietary plasticity in the bivalve Astarte moerchi revealed by a multimarker study in two Arctic fjords. Mar Ecol Prog Ser 567:157-172

Doi H, Akamatsu F, Gonzales AL (2017) Starvation effects on nitrogen and carbon stable isotopes of animals: an insight from meta-analysis of fasting experiments. R Soc Open Sci 4:170633

Falk-Petersen S, Pavlov V, Timofeev S, Sargent JR (2007) Climate variability and possible effects on arctic food chains: the role of Calanus. In: Ørbæk JB, Tombre T, Kallenborn R, Hegseth E, Falk-Petersen S, Hoel AH (eds) Arctic alpine ecosystems and people in a 
657 Gaillard B, Meziane T, Tremblay R, Archambault P, Blicher ME, Chauvaud L, Rysgaard S, Olivier F (2017) Food resources of the bivalve Astarte elliptica in a sub-Arctic fjord: a multi-biomarker approach. Mar Ecol Prog Ser 567:139-156

660

661

662

663

664

665

666

Glud RN, Risgaard-Petersen N, Thamdrup B, Fossing H, Rysgaard S (2000) Benthic carbon mineralization in a high-Arctic sound (Young Sound, NE Greenland). Mar Ecol Prog Ser 206:59-71

Glud RN, Rysgaard S, Kühl M, Hansen JW (2007) The sea ice in Young Sound: Implications for carbon cycling. Medd Grønland Biosci 58:62-85

Hertz E, Trudel M, Cox MK, Mazumder A (2015) Effects of fasting and nutritional restriction on the isotopic ratios of nitrogen and carbon: a meta-analysis. Ecol Evol 5:4829-4839

Hobson KA, Welch HE (1992) Determination of trophic relationships within a high Arctic marine food web using $\delta^{13} \mathrm{C}$ and $\delta^{15} \mathrm{~N}$ analysis. Mar Ecol Prog Ser 84:9-18

Hoch MP, Snyder RA, Cifuentes LA, Coffin RB (1996) Stable isotope dynamics of nitrogen recycled during interactions among marine bacteria and protists. Mar Ecol Prog Ser $132: 229-239$

Iken K, Bluhm BA, Dunton K (2010) Benthic food-web structure under differing water mass properties in the southern Chukchi Sea. Deep Sea Res II 57:71-85

Jacob U, Mintenbeck K, Brey T, Knust R, Beyer K (2005) Stable isotope food web studies: a case for standardized sample treatment. Mar Ecol Prog Ser 287:251-253

Jezyk PF, Penicnak AJ (1966) Fatty acid relationships in an aquatic food chain. Lipids 1:427429 
678 Kędra M, Kuliński K, Walkusz W, Legeżyńska J (2012) The shallow benthic food web structure

679

680

681

682

683

684

685

686

687

688

689

690

691

692

693

694

695

696

697

698

699 in the high Arctic does not follow seasonal changes in the surrounding environment. Estuar Coast Shelf Sci 114:183-191

Kędra M, Moritz C, Choy ES, David C, Degen R, Duerksen S, Ellingsen I, Górska B, Grebmeier JM, Kirievskaya D, van Oevelen D, Piwosz K, Samuelsen A, Wȩsławski JM (2015) Status and trends in the structure of Arctic benthic food webs. Polar Res 34:23775

Kelly JR, Scheibling RE (2012) Fatty acids as dietary tracers in benthic food webs. Mar Ecol Prog Ser 446:1-22

Kjeldsen KK, Korsgaard NJ, Bjørk AA, Khan SA, Box JE, Funder S, Larsen NK, Bamber JL, Colgan W, van den Broeke M, Siggaard-Andersen ML, Nuth C, Schomacker A, Andresen CS, Willerslev E, Kjær KH (2015) Spatial and temporal distribution of mass loss from the Greenland ice sheet since AD 1900. Nature, 528:396-400

Kuliński K, Kędra M, Legeżyńska J, Gluchowska M, Zaborska A (2014) Particulate organic matter sinks and sources in high Arctic fjord. J Mar Syst 139:27-37

Kwok R, Rothrock DA (2009) Decline in Arctic sea ice thickness from submarine and ICESat records: 1958-2008. Geophys Res Lett 36:L15501

Lawson EC, Wadham JL, Tranter M, Stibal M, Lis GP, Butler CEH, Laybourn-Parry J, Nienow P, Chandler D, Dewsbury P (2014) Greenland Ice Sheet exports labile organic carbon to the Arctic oceans. Biogeosciences 11:4015-4028

Lorrain A, Paulet YM, Chauvaud L, Savoye N, Donval A, Saout C (2002) Differential $\delta 13 C$ and $\delta 15 \mathrm{~N}$ signatures among scallop tissues: implications for ecology and physiology. $\mathrm{J}$ Exp Mar Bio Ecol 275:47-61 
Lorrain A, Savoye N, Chauvaud L, Paulet YM, Naulet N (2003) Decarbonation and preservation method for the analysis of organic $\mathrm{C}$ and $\mathrm{N}$ contents and stable isotope ratios of low-carbonated suspended particulate material. Anal Chim Acta 491:125-133

703

704 705

Leroy F, Meziane T, Riera P, Comtet T (2013) Seasonal variations in maternal provisioning of Crepidula fornicata (Gastropoda): fatty acid composition of females, embryos and larvae. PLoS ONE 8:e75316

Leu E, Falk-Petersen S, Kwaśniewski S, Wulff A, Edvardsen K, Hessen DO (2006) Fatty acid dynamics during the spring bloom in a High Arctic fjord: importance of abiotic factors versus community changes. Can J Fish Aquat Sci 63:2760-2779

Leu E, Søreide JE, Hessen DO, Falk-Petersen S, Berge J (2011) Consequences of changing seaice cover for primary and secondary producers in the European Arctic shelf seas: timing, quantity, and quality. Prog Oceanogr 90:18-32

Magen C, Chaillou G, Crowe SA, Mucci A, Sundby B, Gao A, Makabe R, Sasaki H (2010) Origin and fate of particulate organic matter in the southern Beaufort Sea-Amundsen Gulf region, Canadian Arctic. Estuar Coast Shelf Sci 86:31-41

Mayzaud P, Boutoute M, Noyon M, Narcy F, Gasparini S (2013) Lipid and fatty acids in naturally occurring particulate matter during spring and summer in a high arctic fjord (Kongsfjorden, Svalbard). Marine biology 160:383-398

McClintock JB (1994) The trophic biology of Antarctic echinoderms. Mar Ecol Prog Ser $111: 191-202$

McMeans BC, McCann KS, Humphries M, Rooney N, Fisk AT (2015) Food web structure in temporally-forced ecosystems. Trends Ecol Evol 30:662-672 
McPhee MG, Proshutinsky A, Morison JH, Steele M, Alkire MB (2009) Rapid change in freshwater content of the Arctic Ocean. Geophys Res Lett 36:L10602

McTigue ND, Dunton KH (2014) Trophodynamics and organic matter assimilation pathways in the northeast Chukchi Sea, Alaska. Deep Sea Res II 102:84-96

McTigue ND, Bucolo P, Liu Z, Dunton KH (2015) Pelagic-benthic coupling, food webs, and organic matter degradation in the Chukchi Sea: Insights from sedimentary pigments and stable carbon isotopes. Limnol Oceanogr 60:429-445

Meire L, Søgaard DH, Kortensen J, Meysman FJR, Soetaert K, Arendt KE, Juul-Pedersen T, Blicher ME, Rysgaard S (2015) Glacial meltwater and primary production are drivers of strong CO2 uptake in fjord and coastal waters adjacent to the Greenland Ice Sheet. Biogeosciences 12:2347-2363

Meire L, Meire P, Struyf E, Krawczyk DW, Arendt KE, Yde JC, Juul-Pedersen T, Hopwod MJ, Rysgaard S, Meysman FJR (2016) High export of dissolved silica from the Greenland Ice Sheet. Geophys Res Lett 43:9173-9182

Meire L, Mortensen J, Meire P, Juul-Pedersen T, Sejr MK, Rysgaard S, Nygaard R, Huybrechts P, Meysman FJR (2017) Marine-terminating glaciers sustain high productivity in Greenland fjords. Glob Change Biol 23:5344-5357

Meziane T, Tsuchiya M (2000) Fatty acids as tracers of organic matter in the sediment and food web of a mangrove/intertidal flat ecosystem, Okinawa, Japan. Mar Ecol Prog Ser $200: 49-57$

Meziane T, Tsuchiya M (2002) Organic matter in a subtropical mangrove-estuary subjected to wastewater discharge: origin and utilisation by two macrozoobenthic species. J Sea Res $47: 1-11$ 
745 Middelbo AB, Sejr MK, Arendt KE, Møller EF (2018) Impact of glacial meltwater on spatiotemporal distribution of copepods and their grazing impact in Young Sound NE, Greenland. Limnol Oceanogr 63:322-336

Mincks SL, Smith CR, DeMaster DJ (2005) Persistence of labile organic matter and microbial biomass in Antarctic shelf sediments: evidence of a sediment 'food bank'. Mar Ecol Prog Ser 300:3-19

Mincks SL, Smith CR, Jeffreys RM, Sumida PYG (2008) Trophic structure on the West Antarctic Peninsula shelf: Detritivory and benthic inertia revealed by $\delta^{13} \mathrm{C}$ and $\delta^{15} \mathrm{~N}$ analysis. Deep Sea Res II 55: 2502-2514

Moran SB, Lomas MW, Kelly RP, Gradinger R, Iken K, Mathis JT (2012) Seasonal succession of net primary productivity, particulate organic carbon export, and autotrophic community composition in the eastern Bering Sea. Deep Sea Res II 65:84-97

Murray C, Markager S, Stedmon CA, Juul-Pedersen T, Sejr MK, Bruhn A (2015) The influence of glacial melt water on bio-optical properties in two contrasting Greenlandic fjords. Estuar Coast Shelf Sci 163:72-83

Napolitano GE, Ackman RG (1992) Anatomical distributions and temporal variations of lipid classes in sea scallops Placopecten Magellanicus (Gmelin) from Georges Bank (Nova Scotia). Comp Biochem Physiol B 103:645-650

Napolitano GE, Pollero RJ, Gayoso AM, Macdonald BA, Thompson RJ (1997) Fatty acids as trophic markers of phytoplankton blooms in the Bahía Blanca estuary (Buenos Aires, Argentina) and in Trinity Bay (Newfoundland, Canada). Biochem Syst Ecol 25:739-755 
Nérot C, Meziane T, Schaal G, Grall J, Lorrain A, Paulet YM, Kraffe E (2015) Spatial changes in fatty acids signatures of the great scallop Pecten maximus across the Bay of Biscay continental shelf. Cont Shelf Res 109:1-9

Ohashi Y, Iida T, Sugiyama S, Aoki S (2016) Spatial and temporal variations in high turbidity surface water off the Thule region, northwestern Greenland. Polar Sci 10:270-277

Oxtoby LE, Mathis JT, Juranek LW, Wooller, MJ (2016) Estimating stable carbon isotope values of microphytobenthos in the Arctic for application to food web studies. Polar Biol 39:473-483

Parrish CC, Thompson RJ, Deibel D (2005) Lipid classes and fatty acids in plankton and settling matter during the spring bloom in a cold ocean coastal environment. Mar Ecol Prog Ser 286:57-68

Parrish CC (2009) Essential fatty acids in aquatic food webs. In: Arts MT, Brett MT, Kainz MJ (eds) Lipids in aquatic ecosystems. Springer, Dordrecht, p 309-326

Pazos AJ, Sánchez JL, Román G, Luz Pérez-Parallé M, Abad M (2003) Seasonal changes in lipid classes and fatty acid composition in the digestive gland of Pecten maximus. Comp Biochem Physiol B 134:367-380

Pernet F, Tremblay R, Comeau L, Guderley H (2007) Temperature adaptation in two bivalve species from different thermal habitat: energetic and remodeling of membrane lipids. $\mathbf{J}$ Exp Biol 210:2999-3014

Peterson BJ, Fry B (1987) Stable isotopes in ecosystem studies. Ann Rev Ecol Syst 18:293-320

Piquet AMT, Van de Poll WH, Visser RJW, Wiencke C, Bolhuis H, Buma AGJ (2014) Springtime phytoplankton dynamics in Arctic Krossfjorden and Kongsfjorden (Spitsbergen) as a function of glacier proximity. Biogeosciences 11:2263-2279 
R Core Team (2017) R: A language and environment for statistical computing. R Foundation for Statistical Computing, Vienna, Austria

Renaud PE, Tessmann M, Evenset A, Christensen GN (2011) Benthic food-web structure of an Arctic fjord (Kongsfjorden, Svalbard). Mar Biol Res 7:13-26

Reuss N, Poulsen LK (2002) Evaluation of fatty acids as biomarkers for a natural plankton community. A field study of a spring bloom and a post-bloom period off West Greenland. Mar Biol 141: 423-434

Rhead MM, Eglinton G, Draffan GH, England PJ (1971) Conversion of oleic acid to saturated fatty acids in Severn Estuary sediments. Nature 232:327-330

Ribeiro S, Sejr MK, Limoges A, Heikkilä M, Andersen TJ, Tallberg P, Weckström K, Husum K, Forwick M, Dalsgaard T, Massé G, Seidenkrantz MS, Rysgaard S (2017) Sea ice and primary production proxies in surface sediments from a High Arctic Greenland fjord: Spatial distribution and implications for palaeoenvironmental studies. Ambio 46:106118

Rysgaard S, Nielsen TG, Hansen BW (1999) Seasonal variations in nutrients, pelagic primary production and grazing in a high-Arctic coastal marine ecosystem, Young Sound, Northeast Greenland. Mar Ecol Prog Ser 179:13-25

Rysgaard S, Vang T, Stjernholm M, Rasmussen B, Windelin A, Kiilsholm S (2003) Physical conditions, carbon transport, and climate change impacts in a northeast Greenland fjord. Arct Antarct Alp Res 35:301-312

Rysgaard S, Sejr MK (2007) Vertical flux of particulate organic matter in a High Arctic fjord: Relative importance of terrestrial and marine sources. Medd Grønland Biosci 58:110119 
812 Sampei M, Sasaki H, Forest A, Fortier L (2012) A substantial export flux of particulate organic carbon linked to sinking dead copepods during winter 2007-2008 in the Amundsen Gulf (southeastern Beaufort Sea, Arctic Ocean). Limnol Oceanogr 57:90-96

Savoye N, Aminot A, Tréguer P, Fontugne M, Naulet N, Kérouel R (2003) Dynamics of particulate organic matter $\delta 15 \mathrm{~N}$ and $\delta 13 \mathrm{C}$ during spring phytoplankton blooms in a macrotidal ecosystem (Bay of Seine, France). Mar Ecol Prog Ser 255:27-41

Schomburg G (1987) Gaschromatographie Grundlagen, Praxis und Kapillartechnik, 2nd edn. Wiley, VCH, Weinheim, p 62-72

Schulz HD, Zabel M (2006) Marine Geochemistry. Springer-Verlag, Berlin Heidelberg, 574 pp

Sejr MK, Jensen KT, Rysgaard S (2000) Macrozoobenthic structure in a high-Arctic East Greenland fjord. Polar Biol 23:792 -801

Sejr MK, Stedmon CA, Bendtsen J, Abermann J, Juul-Pedersen T, Mortensen J, Rysgaard S (2017) Evidence of local and regional freshening of Northeast Greenland coastal waters. Sci Rep, 7:13183

Silberberger MJ, Renaud PE, Kröncke I, Reiss H (2018) Food-web structure in four locations along the European shelf indicates spatial differences in ecosystem functioning. Front Mar Sci 5:119

Søreide JE, Tamelander T, Hop H, Hobson KA, Johansen I (2006) Sample preparation effects on stable $\mathrm{C}$ and $\mathrm{N}$ isotope values: a comparison of methods in Arctic marine food web studies. Mar Ecol Prog Ser 328:17-28

Søreide JE, Leu E, Berge J, Graeve M, Falk-Petersen S (2010) Timing of blooms, algal food quality and Calanus glacialis reproduction and growth in a changing Arctic. Glob Change Biol 16:3154-3163 
835 Soudant P, Marty Y, Moal J, Robert R, Quéré C, Le Coz JR, Samain JF (1996) Effect of food

836

837 fatty acid and sterol quality on Pecten maximus gonad composition and reproduction process. Aquaculture 143:361-378

Stead RA, Richoux NB, Pereda SV, Thompson RJ (2013) Influence of an intermittent food supply on energy storage by the subpolar deposit feeder Yoldia hyperborea (Bivalvia: Nuculanidae). Polar Biol 36:1333-1345

Tamelander T, Kivimäe C, Bellerby RG, Renaud PE, Kristiansen S (2009) Base-line variations in stable isotope values in an Arctic marine ecosystem: effects of carbon and nitrogen uptake by phytoplankton. Hydrobiologia 630:63-73

Thyrring J, Tremblay R, Sejr MK (2017) Importance of ice algae and pelagic phytoplankton as food sources revealed by fatty acid trophic markers in a keystone species (Mytilus trossulus) from the High Arctic. Mar Ecol Prog Ser 572:155-164

Vizzini S, Mazzola A (2003) Seasonal variations in the stable carbon and nitrogen isotope ratios $\left({ }^{13} \mathrm{C} /{ }^{12} \mathrm{C}\right.$ and $\left.{ }^{15} \mathrm{~N} /{ }^{14} \mathrm{~N}\right)$ of primary producers and consumers in a western Mediterranean coastal lagoon. Mar Biol 142:1009-1018

Wassmann P (2011) Arctic marine ecosystems in an era of rapid climate change. Prog Oceanogr 90:1-17 


\section{FIGURE LEGENDS}

854 Figure 1: Location of the Young Sound's fjord (NE Greenland) and the three sampled stations:

855 Pass Hytten, Basalt Island, and Kap Breusing (modified from Ribeiro et al. 2017).

856 Figure 2: Mean $\delta^{13} \mathrm{C}$ and $\delta^{15} \mathrm{~N}$ values of surface particulate organic matter (s-POM), bottom 857 POM (b-POM), and sedimentary organic matter (SOM) from Pass Hytten (PH), Basalt Island 858 (BI), and Kap Breusing (KB) collected during summer and winter.

859 Figure 3: Mean $\delta^{13} \mathrm{C}$ and $\delta^{15} \mathrm{~N}$ values of Astarte moerchi and Mya truncata tissues and their 860 potential food sources during (A) summer and (B) winter. b-POM: bottom-particulate organic 861 matter, SOM: sedimentary organic matter, DG: digestive gland, MU: muscle. Errors bars 862 represent the standard deviation. Stable isotope values from macroalgae and b-POM, SOM, and 863 Astarte's tissues from wintertime originated from De Cesare (2016) and De Cesare et al. (2017). 

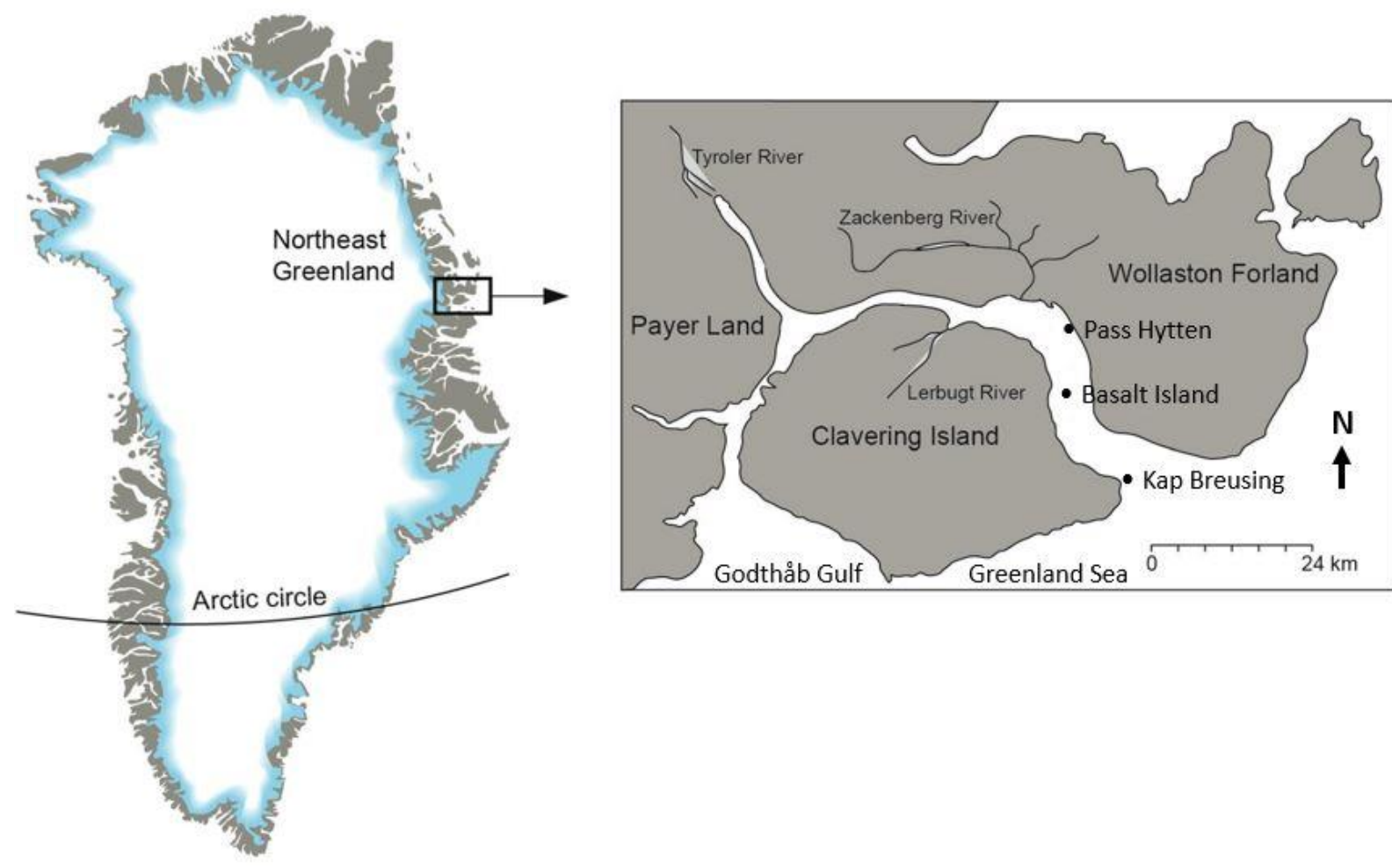

866 


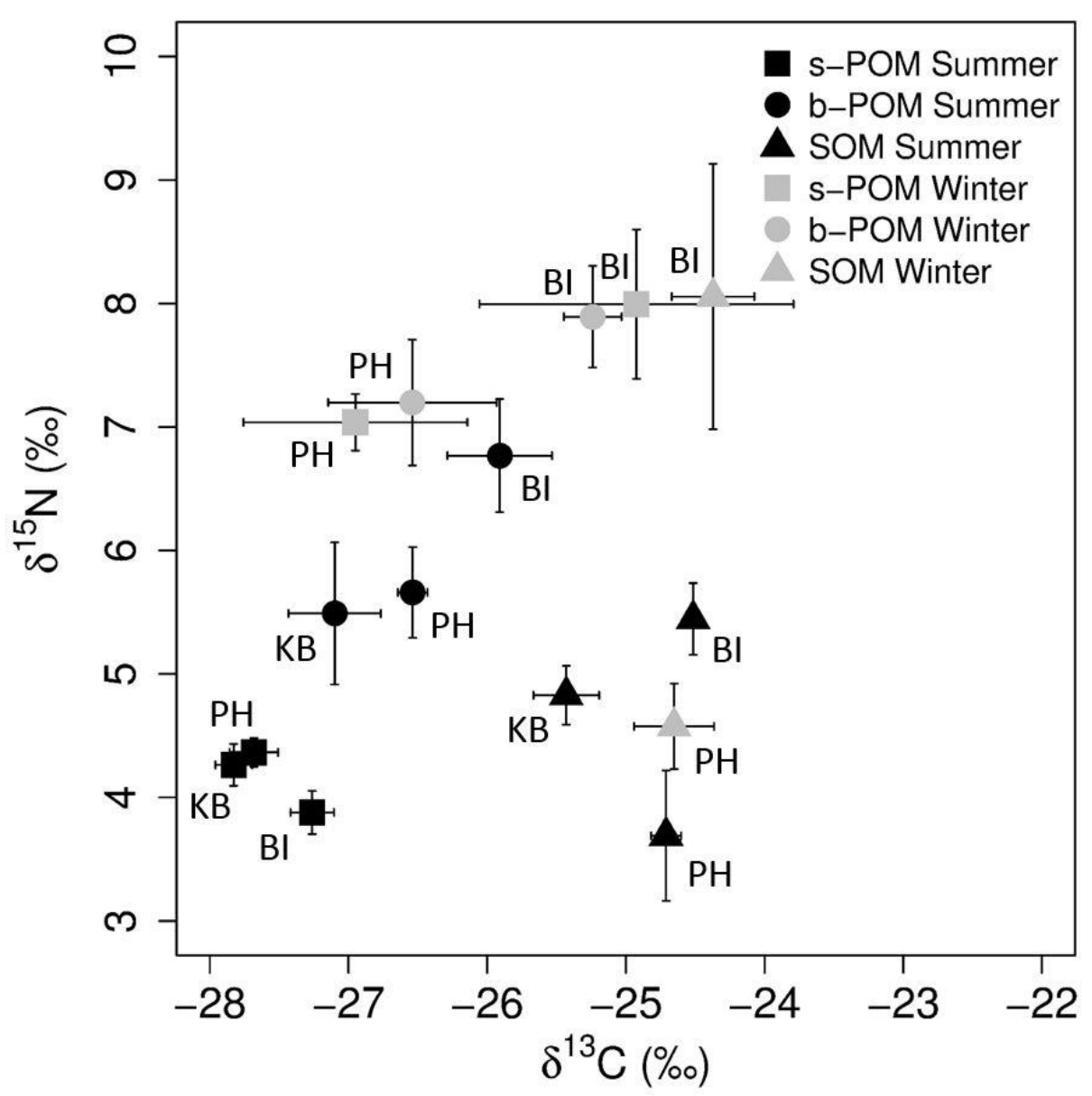

868 


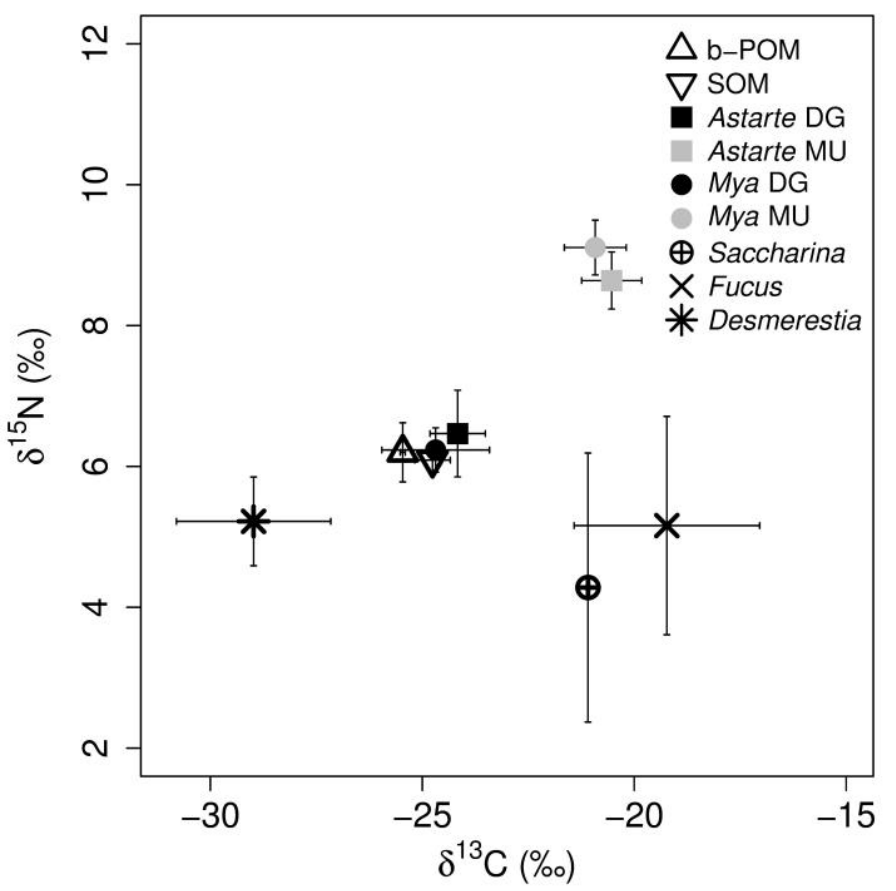

872

A)

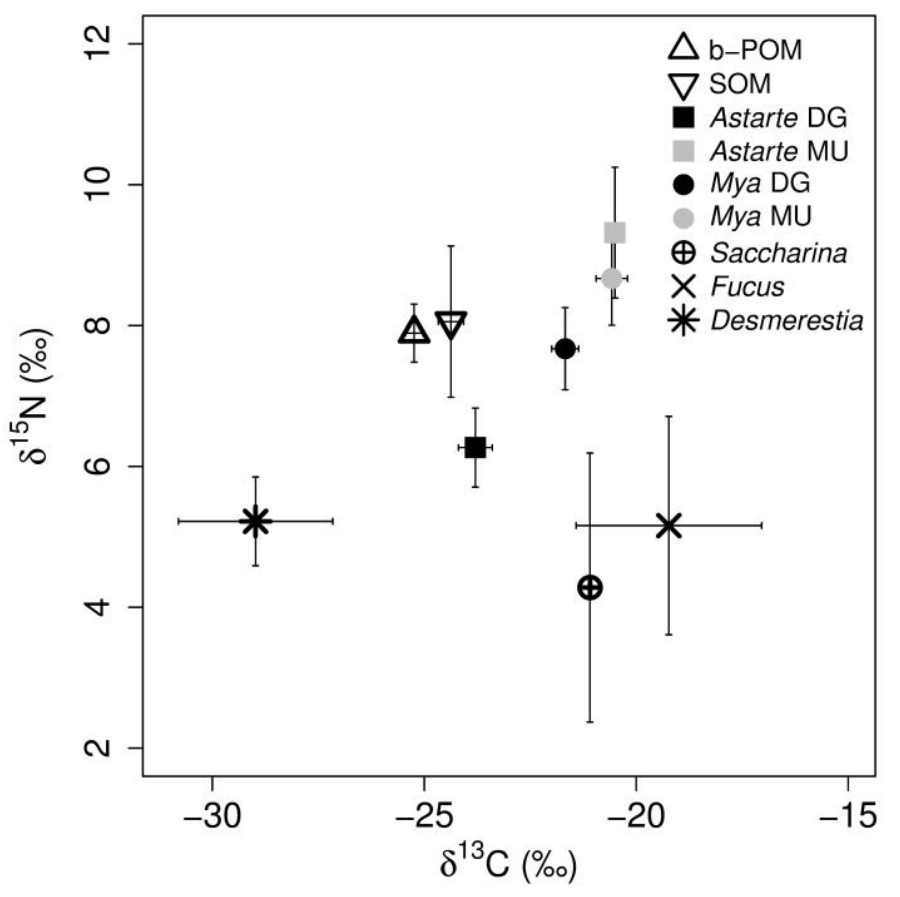

873

B) 
877 Table 1: Fatty acids (FAs) used in this study as markers to describe the origin and quality of 878 organic matter.

879 Table 2: Fatty acid (FA) composition of particulate organic matter (POM) and sedimentary 880 organic matter (SOM) from summer and winter seasons. s-POM: surface POM, b-POM: bottom 881 POM, SFA: saturated FA, MUFA: monounsaturated FA, PUFA: polyunsaturated FA, BrFA:

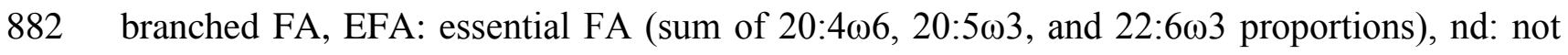
883 detected, tr: trace (FA percentage $<0.2 \%$ ). Standard deviations are represented within brackets. 884 FA percentages lower than $0.2 \%$ in all samples were not included in this table.

885 Table 3: Result of the two-way permutational multivariate analysis of variance 886 (PERMANOVA) realized on the FA composition of summer and winter POM samples based 887 the Bray Curtis dissimilarity matrix. Site (S) and depth (D) are tested as fixed factors. 888 Significant p-values are displayed in bold.

889 Table 4: Fatty acid (FA) composition of digestive gland (DG) and muscle (MU) tissues of 890 Astarte moerchi and Mya truncata collected from Basalt Island and Daneborg during summer 891 and winter. SFA: saturated FA, MUFA: monounsaturated FA, PUFA: polyunsaturated FA,

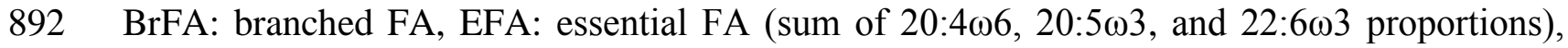
893 EPA/DHA: 20:5 $33 / 22: 6 \omega 3$, nd: not detected, tr: trace (FA percentage $<0.2 \%$ ). Standard 894 deviations are represented within brackets. FA percentages lower than $1 \%$ in all samples are 895 not included in this table. Winter FA compositions of digestive glands and muscles from $A$. 896 moerchi originated from De Cesare (2016) and De Cesare et al. (2017).

897 Table 5: Result of the one-way permutational multivariate analyses of variance 898 (PERMANOVA). The upper part relates to the FA composition of digestive gland (DG) and 899 muscle (MU) tissues of Astarte moerchi and Mya truncata, with season as a fixed factor. The 
900 lower part relates to the FA composition of $A$. moerchi and $M$. truncata from summer (Sum.)

901 and winter (Win.) seasons, with tissue as a fixed factor. 


\section{Table 1}

\begin{tabular}{|c|c|c|}
\hline Descriptor of & Fatty acids (FAs) & References \\
\hline \multicolumn{3}{|l|}{ Organic matter origin } \\
\hline Diatoms & $16: 1 \omega 7,16: 4 \omega 1,20: 5 \omega 3$ & $\begin{array}{l}\text { Reuss \& Poulsen (2002), Dalsgaard et al. (2003), Kelly \& Scheibling } \\
\text { (2012) }\end{array}$ \\
\hline Dinoflagellates & $18: 4 \omega 3,22: 6 \omega 3$ & Napolitano et al. (1997), Kelly \& Scheibling (2012) \\
\hline Macroalgae (Phaeophyceae) & $18: 2 \omega 6,18: 3 \omega 3,18: 4 \omega 3,20: 5 \omega 3$ & Kelly \& Scheibling (2012), De Cesare et al. (2017), Gaillard et al. (2017) \\
\hline \multicolumn{3}{|l|}{ Organic matter quality } \\
\hline Degraded organic matter & Dominance of SFA (e.g., 14:0, 16:0, 18:0) & Rhead et al. (1971), Connelly et al. (2015), Connelly et al. (2016) \\
\hline $\begin{array}{l}\text { Labile and nutritionally rich } \\
\text { organic matter }\end{array}$ & $\begin{array}{l}\text { Dominance of PUFA and EFA (here, sum of } \\
20: 4 \omega 6,20: 5 \omega 3 \text {, and } 22: 6 \omega 3 \text { ) }\end{array}$ & Soudant et al. (1996), Parrish et al. (2005), Parrish (2009) \\
\hline
\end{tabular}

903 


\begin{tabular}{|c|c|c|c|c|c|c|c|c|c|c|c|c|}
\hline & \multicolumn{7}{|c|}{ August } & \multicolumn{5}{|c|}{ May } \\
\hline & \multicolumn{2}{|c|}{ Pass Hytten } & \multicolumn{2}{|c|}{ Basalt Island } & \multicolumn{2}{|c|}{ Kap Breusing } & \multirow{2}{*}{ SOM } & \multicolumn{2}{|c|}{ Pass Hytten } & \multicolumn{2}{|c|}{ Basalt Island } & \multirow{3}{*}{$\begin{array}{l}\text { SOM } \\
\mathrm{N}=9\end{array}$} \\
\hline & s-POM & b-POM & s-POM & b-POM & s-POM & b-POM & & s-POM & b-POM & s-POM & b-POM & \\
\hline & $\mathrm{N}=5$ & $\mathrm{~N}=5$ & $\mathrm{~N}=5$ & $\mathrm{~N}=4$ & $\mathrm{~N}=5$ & $\mathrm{~N}=4$ & $\mathrm{~N}=10$ & $\mathrm{~N}=4$ & $\mathrm{~N}=4$ & $\mathrm{~N}=5$ & $\mathrm{~N}=5$ & \\
\hline $12: 0$ & nd & nd & nd & nd & nd & nd & nd & $1.6(0.7)$ & $3.7(1.3)$ & $6.6(4.8)$ & $2.4(0.6)$ & $1.6(1.1)$ \\
\hline 13:0 & nd & nd & nd & nd & nd & nd & nd & $\operatorname{tr}$ & $0.3(0.2)$ & $\operatorname{tr}$ & $\operatorname{tr}$ & $0.3(0.1)$ \\
\hline $14: 0$ & $17.8(6.2)$ & $7.1(1.6)$ & $19.9(7)$ & $8.5(1.6)$ & $12.9(3.6)$ & $8.4(0.8)$ & $9.7(3.7)$ & $7.5(0.3)$ & $7.4(0.9)$ & $13.2(2.7)$ & $9(1)$ & $6.3(1.7)$ \\
\hline $15: 0$ & $1.3(0.3)$ & $1.8(0.3)$ & $1.5(0.3)$ & $2.1(0.5)$ & $1.3(0.3)$ & $1.3(0.2)$ & $1(0.3)$ & $2.7(0.3)$ & $2.3(0.4)$ & $2.5(0.4)$ & $2.8(0.5)$ & $1.7(0.3)$ \\
\hline $16: 0$ & $35.3(9.8)$ & $32.9(4.9)$ & $45.1(8.7)$ & $36(7.9)$ & $31.5(3.3)$ & $27.1(4.8)$ & $34.2(6.4)$ & $43(0.8)$ & $41.1(1.7)$ & $38.6(5.3)$ & $39.5(6.3)$ & $46(3)$ \\
\hline $17: 0$ & $0.8(0.2)$ & $1.1(0.2)$ & $1.1(0.5)$ & $1.5(0.6)$ & $0.8(0.2)$ & $0.8(0.2)$ & $0.6(0.6)$ & $1.6(0.1)$ & $1.3(0.1)$ & $1.3(0.2)$ & $1.6(0.3)$ & $1.3(0.2)$ \\
\hline 18:0 & $7.5(2.8)$ & $20.1(4.2)$ & $13.5(4.8)$ & $17.6(3.4)$ & $8.7(1.3)$ & $9.8(2)$ & $9(7.7)$ & $31.8(3)$ & $30.5(6.4)$ & $21.6(3.7)$ & $22.5(3.4)$ & $30.5(4.2)$ \\
\hline $19: 0$ & $0.5(0.2)$ & $0.3(0.2)$ & $0.7(0.2)$ & $0.9(0.5)$ & $0.5(0.1)$ & $0.3(0.2)$ & $0.5(0.5)$ & nd & nd & tr & nd & nd \\
\hline $20: 0$ & $0.3(0.1)$ & $0.9(0.1)$ & $0.5(0.4)$ & $0.8(0.2)$ & $0.5(0.2)$ & $0.5(0.1)$ & $0.4(0.4)$ & $1.6(0.0)$ & $1.3(0.1)$ & $1.1(0.2)$ & $1.2(0.1)$ & $1.4(0.1)$ \\
\hline $21: 0$ & $0.3(0.3)$ & $0.2(0.1)$ & $0.6(0.4)$ & $0.3(0.3)$ & $0.4(0.5)$ & $\operatorname{tr}$ & $0.3(0.4)$ & $\operatorname{tr}$ & $0.2(0.2)$ & $0.3(0.2)$ & $0.3(0)$ & $\operatorname{tr}$ \\
\hline $22: 0$ & $0.5(0.2)$ & $0.8(0.1)$ & $0.8(0.3)$ & $0.6(0.2)$ & $0.5(0.1)$ & $0.5(0.1)$ & $0.5(0.4)$ & $1.2(0.1)$ & $1.0(0.1)$ & $1(0.3)$ & $1.2(0.3)$ & $1.2(0.1)$ \\
\hline $24: 0$ & $0.3(0)$ & $0.7(0.3)$ & $0.5(0.2)$ & $0.9(0.2)$ & $0.4(0.2)$ & $0.6(0.1)$ & $0.7(0.5)$ & $1.7(0.1)$ & $1.1(0.3)$ & $1.5(0.4)$ & $1.5(0.3)$ & $1.5(0.3)$ \\
\hline $25: 0$ & nd & nd & nd & nd & nd & nd & nd & $0.3(0.0)$ & $0.2(0.0)$ & $0.2(0.1)$ & $0.3(0.1)$ & $0.8(1.3)$ \\
\hline$\Sigma$ SFA & $64.5(15.2)$ & $65.8(9.5)$ & $84.4(14.2)$ & $69.3(14.2)$ & $57.4(6.7)$ & $49.5(6.9)$ & $56.9(15.7)$ & $93.1(2.6)$ & $90.4(5.4)$ & $88.4(10.1)$ & $82.5(11.3)$ & $92.8(2.6)$ \\
\hline $14: 1 \omega 5$ & nd & nd & nd & nd & nd & nd & nd & $\operatorname{tr}$ & $0.2(0.2)$ & $0.2(0.1)$ & $\operatorname{tr}$ & $0.2(0.2)$ \\
\hline $15: 1 \omega 1$ & nd & nd & nd & nd & nd & nd & nd & $0.3(0.7)$ & $1.0(1.4)$ & $1.1(0.6)$ & $0.6(0.5)$ & $0.7(0.8)$ \\
\hline $16: 1 \omega 5$ & $1.1(0.5)$ & $0.6(0.3)$ & $0.3(0.3)$ & $0.4(0.2)$ & $1.2(0.2)$ & $0.8(0.1)$ & $0.3(0.2)$ & nd & nd & nd & nd & nd \\
\hline $16: 1 \omega 7$ & $7.8(3.3)$ & $6.9(1.6)$ & $4(5.4)$ & $6.6(4.6)$ & $9.4(1.6)$ & $12(1.2)$ & $18.3(7.8)$ & $0.4(0.3)$ & $0.4(0.4)$ & $0.6(0.7)$ & $0.9(0.6)$ & tr \\
\hline $16: 1 \omega 9$ & $0.7(0.2)$ & $1.7(0.5)$ & $0.4(0.5)$ & $1.9(1.2)$ & $0.9(0.1)$ & $1.2(0.4)$ & $0.9(0.5)$ & $0.3(0.1)$ & $0.3(0.1)$ & $0.6(0.9)$ & $1.2(1)$ & $0.3(0.2)$ \\
\hline $17: 1 \omega 7$ & $0.2(0.1)$ & $0.2(0.1)$ & $\operatorname{tr}$ & $0.2(0.2)$ & $0.2(0.1)$ & $0.2(0.1)$ & $\operatorname{tr}$ & nd & nd & $\operatorname{tr}$ & nd & nd \\
\hline $17: 1 \omega 9$ & $\operatorname{tr}$ & $\operatorname{tr}$ & $\operatorname{tr}$ & $\operatorname{tr}$ & $\operatorname{tr}$ & $\operatorname{tr}$ & $\operatorname{tr}$ & $\operatorname{tr}$ & $0.2(0.1)$ & $0.2(0.1)$ & $\operatorname{tr}$ & $\operatorname{tr}$ \\
\hline $18: 1 \omega 5$ & $\operatorname{tr}$ & $0.3(0.2)$ & $0.2(0.2)$ & $0.3(0.1)$ & $0.2(0)$ & $0.3(0.1)$ & tr & $\operatorname{tr}$ & $\mathrm{tr}$ & tr & $0.3(0.2)$ & $\operatorname{tr}$ \\
\hline $18: 1 \omega 7$ & $1.9(0.7)$ & $2.2(0.6)$ & $1(1.3)$ & $1.4(0.7)$ & $3(1.1)$ & $2.5(0.9)$ & $2.4(1)$ & $0.2(0.2)$ & $0.4(0.3)$ & $0.5(0.6)$ & $1.1(0.4)$ & $0.3(0.5)$ \\
\hline $18: 1 \omega 9$ & $7.1(2.7)$ & $6.7(2)$ & $1.9(2.7)$ & $6.2(4.1)$ & $9.7(2.2)$ & $6.4(0.9)$ & $6(2.1)$ & $0.7(0.8)$ & $2.9(4.8)$ & $3.2(6.2)$ & $7.3(8)$ & $0.5(1)$ \\
\hline $20: 1 \omega 7$ & $0.3(0.3)$ & tr & tr & $0.2(0.1)$ & $0.5(0.3)$ & $0.8(0.6)$ & tr & tr & $0.4(0.4)$ & $0.3(0.2)$ & $0.5(0.2)$ & nd \\
\hline $20: 1 \omega 9$ & $0.3(0.2)$ & $0.2(0.1)$ & nd & $\operatorname{tr}$ & $\operatorname{tr}$ & $0.2(0.1)$ & $\operatorname{tr}$ & $0.8(1.4)$ & $0.5(0.8)$ & $0.2(0.3)$ & $0.2(0.2)$ & $0.2(0.3)$ \\
\hline $22: 1 \omega 9$ & tr & tr & $\operatorname{tr}$ & $\operatorname{tr}$ & tr & $0.3(0.1)$ & $\operatorname{tr}$ & nd & nd & $\operatorname{tr}$ & tr & nd \\
\hline $22: 1 \omega 11$ & $0.4(0.3)$ & $\mathrm{tr}$ & $\operatorname{tr}$ & $\operatorname{tr}$ & $0.4(0.3)$ & $0.7(0.5)$ & $\operatorname{tr}$ & nd & nd & $0.5(0.8)$ & $0.2(0.1)$ & nd \\
\hline$\Sigma$ MUFA & $20.1(7)$ & $19.4(4.9)$ & $8(10.9)$ & $17.9(10.3)$ & $26(4.4)$ & $25.6(1.6)$ & $28.6(10.7)$ & $3.2(1.4)$ & $6.2(5.2)$ & $8(8.5)$ & $13.1(10.3)$ & $2.8(2.3)$ \\
\hline $16: 2 \omega 4$ & $\operatorname{tr}$ & $\operatorname{tr}$ & $\operatorname{tr}$ & $\operatorname{tr}$ & $\operatorname{tr}$ & $0.4(0.1)$ & $0.3(0.2)$ & nd & nd & nd & nd & $\mathrm{nd}$ \\
\hline $16: 2 \omega 6$ & $\operatorname{tr}$ & $\operatorname{tr}$ & $\operatorname{tr}$ & $\operatorname{tr}$ & $\operatorname{tr}$ & tr & $0.2(0.3)$ & nd & nd & nd & nd & nd \\
\hline $16: 3 \omega 3$ & $\operatorname{tr}$ & $\operatorname{tr}$ & nd & $\operatorname{tr}$ & nd & $0.3(0.2)$ & $0.2(0.2)$ & nd & nd & nd & nd & nd \\
\hline $16: 4 \omega 1$ & $\operatorname{tr}$ & $0.2(0.1)$ & $\operatorname{tr}$ & $0.4(0.2)$ & $\operatorname{tr}$ & $1.1(0.5)$ & $0.6(0.3)$ & nd & nd & nd & nd & nd \\
\hline $16: 4 \omega 3$ & $0.6(0.3)$ & $0.4(0.2)$ & $0.2(0.2)$ & $0.4(0.1)$ & $0.6(0.1)$ & $0.7(0.2)$ & $0.4(0.3)$ & nd & nd & nd & nd & nd \\
\hline $18: 2 \omega 6$ & $1.3(0.8)$ & $1.9(0.7)$ & $0.5(0.8)$ & $2.8(1.4)$ & $1.9(0.4)$ & $2.6(0.3)$ & $2(0.9)$ & $\operatorname{tr}$ & $0.3(0.4)$ & $0.5(0.9)$ & $1.1(1.3)$ & $\operatorname{tr}$ \\
\hline $18: 3 \omega 3$ & $0.9(0.7)$ & $0.6(0.2)$ & $0.3(0.5)$ & $0.7(0.2)$ & $1.2(0.3)$ & $0.8(0.1)$ & $0.5(0.3)$ & $\operatorname{tr}$ & $\mathrm{tr}$ & $0.2(0.1)$ & $0.2(0.1)$ & $\operatorname{tr}$ \\
\hline $18: 4 \omega 3$ & $1.7(1.4)$ & $1.3(0.4)$ & $0.3(0.5)$ & $0.7(0.3)$ & $1.9(0.6)$ & $2.4(0.2)$ & $0.5(0.4)$ & nd & nd & $\operatorname{tr}$ & nd & nd \\
\hline $20: 4 \omega 6$ & $\operatorname{tr}$ & $\operatorname{tr}$ & nd & tr & nd & $\operatorname{tr}$ & $0.2(0.2)$ & nd & nd & $\operatorname{tr}$ & nd & nd \\
\hline $20: 5 \omega 3$ & $2.6(2.2)$ & $3.7(2.1)$ & $0.7(1)$ & $2.7(2.5)$ & $2.7(1)$ & $9(4.9)$ & $6.2(3.3)$ & nd & nd & $\operatorname{tr}$ & nd & nd \\
\hline $22: 2 \omega 9$ & $\operatorname{tr}$ & $\operatorname{tr}$ & $0.4(0.5)$ & $0.3(0.3)$ & $\operatorname{tr}$ & $0.2(0.1)$ & $0.5(0.4)$ & nd & nd & nd & nd & nd \\
\hline $22: 5 \omega 3$ & $\operatorname{tr}$ & $0.3(0.2)$ & nd & $0.5(0.2)$ & tr & $0.4(0.1)$ & $0.3(0.6)$ & nd & nd & $\operatorname{tr}$ & nd & nd \\
\hline $22: 6 \omega 3$ & $3.7(3.5)$ & $2.4(1.3)$ & $0.6(0.9)$ & $0.9(0.6)$ & 4 (1.4) & $3.6(0.9)$ & $0.8(0.7)$ & $\mathrm{tr}$ & nd & tr & tr & $\operatorname{tr}$ \\
\hline$\Sigma$ PUFA & $11.6(9.2)$ & $11.4(5)$ & $3.1(4)$ & $9.7(5.1)$ & $13(3.9)$ & $22.1(6.7)$ & $12.9(5.9)$ & $0.2(0.1)$ & $0.3(0.4)$ & $1.1(1.6)$ & $1.5(1.5)$ & $\operatorname{tr}$ \\
\hline$\Sigma$ BrFA & $3.8(0.7)$ & $3.4(0.4)$ & $4.5(0.6)$ & $3.2(0.9)$ & $3.6(0.5)$ & $2.8(0.6)$ & $1.6(0.5)$ & $3.5(1.9)$ & $3.1(1.2)$ & $2.5(0.2)$ & $2.9(0.9)$ & $4.2(1)$ \\
\hline$\Sigma$ PUFA/ $\Sigma$ SFA & $0.2(0.3)$ & $0.2(0.1)$ & $0.0(0.1)$ & $0.2(0.1)$ & $0.2(0.1)$ & $0.5(0.2)$ & $0.3(0.2)$ & $\operatorname{tr}$ & $\mathrm{tr}$ & $0.0(0.0)$ & $0.0(0.0)$ & $0.0(0.0)$ \\
\hline$\Sigma$ EFA & $6.4(5.7)$ & $6.2(3.4)$ & $1.2(1.9)$ & $3.6(3.1)$ & $6.8(2.4)$ & $12.7(5.8)$ & $7.2(3.9)$ & $\operatorname{tr}$ & nd & $\operatorname{tr}$ & $\mathrm{tr}$ & $\operatorname{tr}$ \\
\hline $16: 1 \omega 7 / 16: 0$ & $0.3(0.2)$ & $0.2(0.1)$ & $0.1(0.2)$ & $0.2(0.2)$ & $0.3(0.1)$ & $0.5(0.1)$ & $0.6(0.3)$ & $\operatorname{tr}$ & $\operatorname{tr}$ & $0.0(0.0)$ & $0.0(0.0)$ & $0.0(0.0)$ \\
\hline$[\mathrm{FA}](\mathrm{mg} / \mathrm{g})$ & $8.0(2.1)$ & $9.5(5.0)$ & $2.6(0.9)$ & $11.3(4.4)$ & $9.4(2.3)$ & $7.2(5.7)$ & $0.7(0.4)$ & $3.9(0.5)$ & $4.9(2.5)$ & $5.8(2.4)$ & $8.4(4.4)$ & $0.2(0.0)$ \\
\hline
\end{tabular}

905 
Table 3

\begin{tabular}{|cccccc|}
\hline $\begin{array}{c}\text { Source of } \\
\text { variation }\end{array}$ & df & MeanSqs & F Model & $\mathrm{R}^{2}$ & p-value \\
\hline Site (S) & 2 & 0.1360 & 5.7102 & 0.2809 & $\mathbf{0 . 0 0 1 4}$ \\
Depth (D) & 1 & 0.1327 & 5.5725 & 0.1371 & $\mathbf{0 . 0 0 5 2}$ \\
S x D & 2 & 0.0198 & 0.8324 & 0.0410 & 0.5088 \\
Residuals & 22 & 0.0238 & & 0.5411 & \\
& & & POM - Winter & & \\
& df & MeanSqs & F Model & $\mathrm{R}^{2}$ & p-value \\
\hline Site (S) & 1 & 0.0494 & 4.7766 & 0.2137 & $\mathbf{0 . 0 0 1 4}$ \\
Depth (D) & 1 & 0.0251 & 2.4328 & 0.1088 & $\mathbf{0 . 0 4 9 4}$ \\
S x D & 1 & 0.0222 & 2.1470 & 0.0960 & 0.0766 \\
Residuals & 13 & 0.0103 & & 0.5815 & \\
\hline
\end{tabular}

907

908 


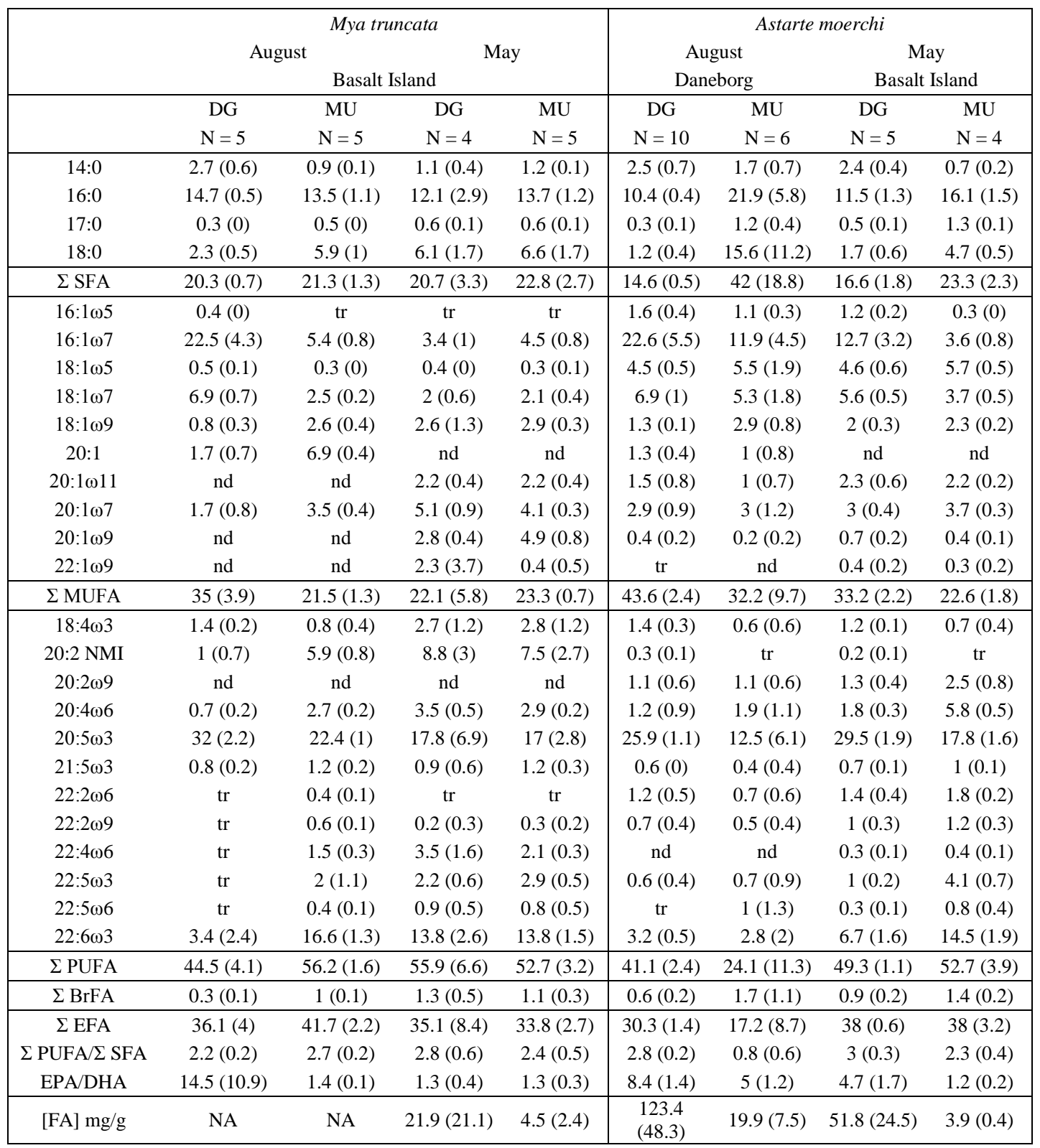


Table 5

\begin{tabular}{|cccccc|}
\hline \multirow{2}{*}{ Tested group } & df & MeanSqs & F Model & $\mathrm{R}^{2}$ & p-value \\
\hline M. truncata DG & 1 & 0.4866 & 36.8920 & 0.8405 & $\mathbf{0 . 0 0 6 2}$ \\
M. truncata MU & 1 & 0.0931 & 20.9360 & 0.7235 & $\mathbf{0 . 0 0 7 4}$ \\
A. moerchi DG & 2 & 0.1092 & 16.6220 & 0.6129 & $\mathbf{0 . 0 0 0 1}$ \\
A. moerchi MU & 2 & 0.2220 & 7.2209 & 0.4593 & $\mathbf{0 . 0 0 0 5}$ \\
& & & Tissue as fixed factor & \\
& df & MeanSqs & F Model & $\mathrm{R}^{2}$ & p-value \\
\hline M. truncata May. & 1 & 0.0166 & 1.175 & 0.1437 & 0.3220 \\
A. moerchi May. & 1 & 0.3243 & 99.035 & 0.9253 & $\mathbf{0 . 0 0 8 4}$ \\
A. moerchi Aug. & 1 & 0.4510 & 48.958 & 0.7776 & $\mathbf{0 . 0 0 0 1}$ \\
\end{tabular}

913 